\title{
ASSOCIATIONAL NETWORKS \\ AND WELFARE STATES IN \\ ARGENTINA, BRAZIL, SOUTH \\ KOREA, AND TAIWAN
}

\author{
By CHEOL-SUNG LEE*
}

\begin{abstract}
$\Lambda$ FTER the third wave of democratization, many developing countries under authoritarian governments experienced transitions to democratic regimes. The need to respond to citizens' demands for redistribution via social welfare became one of the most important items on the political agenda for leaders of political parties in many "democratized" developing countries. In addition, accelerated economic globalization in the late twentieth century drove leaders and citizens of new democracies to increasingly vulnerable positions vis-à-vis economic crises, shocks, and fluctuations in world markets.

However, political elites in the new democracies, just as in developed countries, have shown markedly different responses to these pressures from below and outside. Some countries have enjoyed dramatic expansion of the welfare state, while others have suffered radical retrenchment in the public sector. What factors account for these strikingly different trajectories of social policy development in emerging economies with newly institutionalized democracy?

To answer this question, the article focuses on four country cases: Argentina, Brazil, South Korea, and Taiwan. I chose these cases for a number of reasons. First, all four countries share similar conditions that facilitate intriguing cross-national, comparative-historical comparisons. They have achieved medium (Argentina and Brazil) to up-
\end{abstract}

\footnotetext{
* For their valuable comments, I thank Jason Beckfield, Seok-Ju Cho, Rick Donor, Terry Clark, Mark Deming, Yong-Kyun Kim, Alex Hicks, Edward Laumann, John Levi Martin, Cristina Mora, Jong-Hee Park, Monica Prasad, and Andrew Schrank, as well as participants in the University of Chicago Comparative Politics Workshop, the Institute for Developing Nations Workshop at Emory University, and the Center for East Asian and Pacific Studies workshop at University of Illinois at Urbana Champaign. This research was supported by the University of Chicago Social Sciences Division Research Grant.
}

World Politics 64, no. 3 (July 2012), 507-54

Copyright (C) 2012 Trustees of Princeton University

doi: S0043887112000111 
per (South Korea and Taiwan) middle levels of development, and thus social demands for public provisions of welfare have emerged in functional, demographic, and political contexts; in turn, the expansion or retrenchment of social policies has become a critical battleground in formal politics. In addition, all four countries experienced democratization in the 1980s and subsequently consolidated democratic political institutions in the 1990s and the 2000s. Significantly, all four countries suffered economic crises in the late twentieth century: the two Latin American cases have had endemic and chronic debt crises and extremely high inflation, situations that were exacerbated in the 1980s and 1990s (see Appendix 1 for statistics), while the two East Asian cases suffered from the Asian Financial Crisis in 1997 and subsequent recessions, if to different degrees. These similarities allow us to control for some alternative economic, political, and structural factors that might otherwise account for variations in the dynamics of welfare states among these countries.

Second, I intentionally chose two East Asian and two Latin American countries with similar cultural and geopolitical histories. In this way, I can readily control for several known or unknown region-specific factors. Taiwan and South Korea share very similar modern histories such as colonization by Japan; American military occupation followed by the Cold War and ensuing ideological confrontation; rapid state-led, export-oriented economic development under authoritarian regimes; and strong Confucian culture. Argentina and Brazil also share similar geographical and cultural similarities such as Catholic-dominant religious identities, as well as highly unequal and volatile economic structures; traditions of populist politics; and pronounced influence of landed aristocracy and international capital.

Finally, despite their similarities, these four developing countries have considerable and potentially quite illuminating diversity in their histories of social welfare regimes. First, the development and retrenchment of welfare states in Argentina and Brazil provide intriguing cases for comparison. These two countries have followed sharply different trajectories of social, political, and economic transformations in the 1990s and 2000s, as shown in Table 1. While Argentina has embraced neoliberal market reforms on public sector and social policies after experiencing a serious debt crisis, Brazil has not adopted them wholeheartedly. Argentina has launched a relatively radical privatization of pensions, cut the public share in total health spending, and then decreased benefits in family allowances. Brazil, by contrast, has not only durably resisted market-oriented reforms of key social policy 


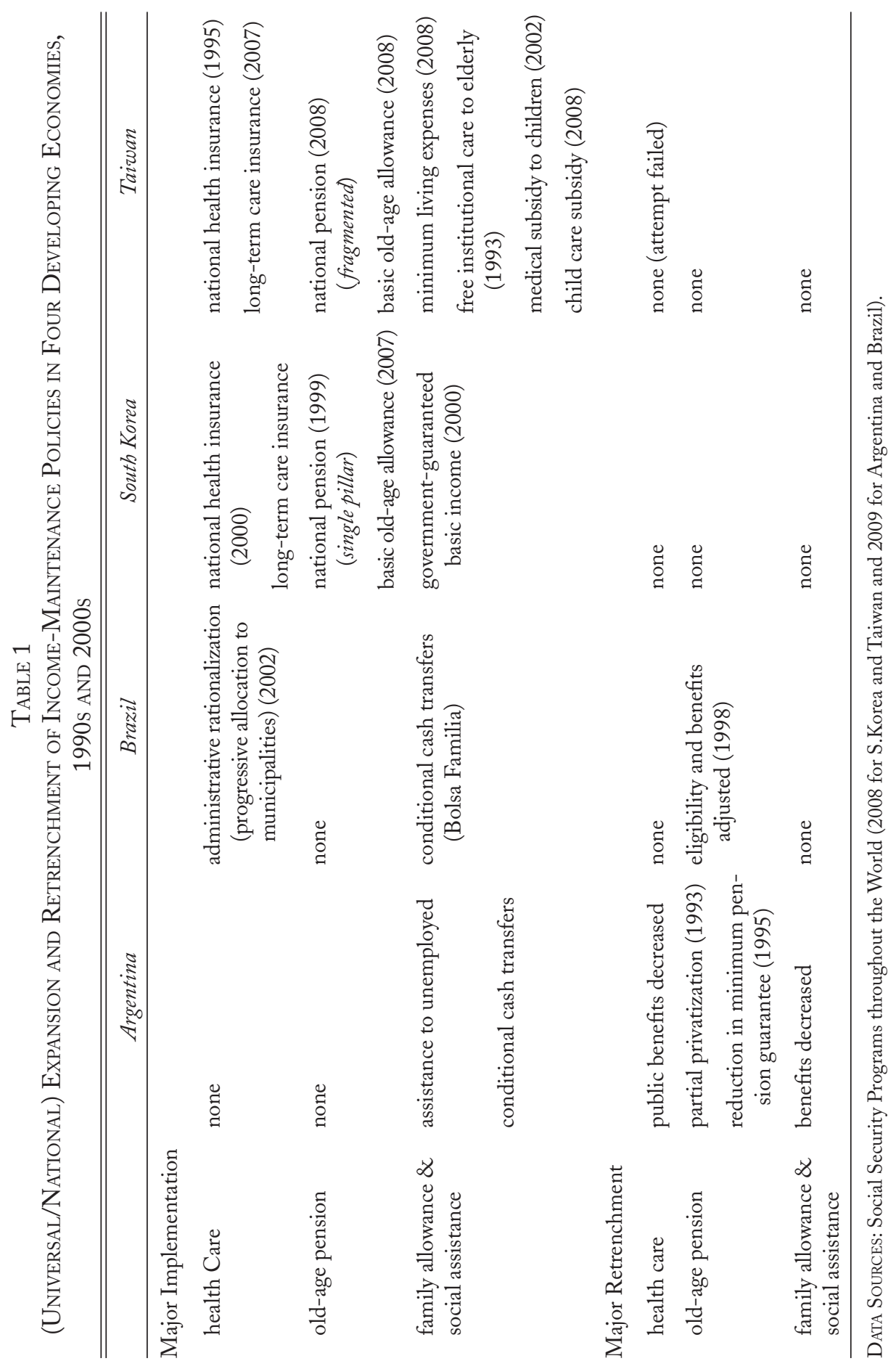


areas such as pensions, but it has also dramatically increased government spending for total health care expenditure. Overall, Brazil has delivered success stories of escape from economic crisis, rapid growth rates, preservation of the existing public sector, and impressive reduction in poverty rates.

The recent development stories of welfare states in South Korea and Taiwan are no less intriguing. As Table 1 shows, during the course of democratic consolidation, both countries introduced not only universal health care and national pension programs but also basic old-age pension and long-term care insurance mainly targeting the disabled and the elderly population living under the poverty line (basic income and pension) or of middle-class origin (long-term care insurance). In addition, both countries introduced government-guaranteed basic income as a social assistance program. However, even if these two countries share many preexisting conditions and commonly operating causal forces, such as the growth of influential pro-welfare civil society groups, there is also a growing and significant difference in how they deliver on their social policies. On the spending side, Taiwan has increased its overall social expenditure level faster than South Korea, thanks to its generous income-maintenance policies, mainly in the form of direct cashtransfer programs (see family allowance/social assistance in Table 1). On the institutional side, however, South Korea has succeeded in launching more universal types of programs with greater potential to increase spending in the future. ${ }^{1}$

These differences between Argentina and Brazil and between Taiwan and Korea become even more puzzling, given that the major retrenchment in Argentina was propelled by a labor-based party, the PJ (the Justicialist Party), whereas the implementation and expansion of key social policies in Taiwan were driven by the right-wing (semiauthoritarian) party, the KMT (the Kuomintang, the Chinese Nationalist Party). Why did a formerly labor-based party suddenly betray the poor and working class in Argentina but not in Brazil? Why did the

\footnotetext{
${ }^{1}$ This study focuses more on the institutional expansion or retrenchment of major social programs (especially public pension and health care) as an dependent variable than on the size of public expenditure on those programs, a conventional measure of welfare state efforts, for the following reason: the effects of a universal social policy, for example, pension, on a spending measure are realized over a long span of time. Therefore, a significant policy change as an outcome of political struggles or economic conditions does not lead to an immediate increase in the spending measure. As this study analyzes the mechanism of social policy change for relatively a short time period (the 1990s and the 2000s), it is important to consider the expansion or retrenchment of major social policies as a qualitative outcome. Among major social policy areas, this study puts the primary focus on income-maintenance policies such as old-age pensions and social assistance programs.
} 
right-wing (formerly) authoritarian party initiate the expansion of key social policies in Taiwan? But why are universal social policies increasingly gaining popular support in South Korea, deepening traditional right-wing versus left-wing partisan confrontations along the line of targeted versus universal policies, while politicians in Taiwan have been jockeying to provide more generous cash-transfer programs, regardless of partisan affiliation?

In reviewing the theories that have been developed to account for advanced industrial democracies, I find that existing representative theories of welfare state development have some explanatory power for variations among these countries but do not fully answer the questions I raise here. The most commonly cited explanations of welfare state expansion-demographic pressure (increasing old-age population) coupled with the logics of industrialism ${ }^{2}$ and the theory of economic openness ${ }^{3}$ - may reasonably explain the introduction of universal health care in Taiwan and South Korea but cannot explain why the two countries then increasingly followed different paths since the late 1990s. Both theories also have their limits in explaining the different trajectories of the welfare states in Argentina and Brazil, as they have similar openness levels and demographic structures. Another influential theory of welfare state development, the "statecentric" approach, ${ }^{4}$ may effectively explain earlier phases of partial, selective social policy developments (targeting state officials and public sector employees) initiated by authoritarian regimes in these countries. Nonetheless, both the role of bureaucrats and the legacies of past policies, which were largely identical in the two East Asian and the two Latin American countries, respectively, are not likely to give an adequate answer to the questions above regarding "radical departures" of social policies from the previous trajectories. The power-resource theory school ${ }^{5}$ also has only a limited ability to account for the variations, as the organizational power resources of labor-based reformist parties and unions were largely similar in the 1990s in Argentina and Brazil. Even if South Korean labor movements are known to be stronger in their mobilization capacity than their Taiwanese counterparts, labor itself did not play a significant role in the expansion of universal social policies in South Korea.

In this study, I propose an analytical model in line with "the configuration of civil society" argument earlier introduced by Ruschemeyer,

${ }^{2}$ Wilensky 1975; Pampel and Williamson 1988.

${ }^{3}$ Cameron 1978; Katzenstein 1985.

${ }^{4}$ Heclo 1974; Skocpol 1992.

${ }^{5}$ Esping-Andersen 1985; Korpi 1983; Stephens 1979. 
Stephens, and Stephens ${ }^{6}$ and by Collier and Collier. ${ }^{7}$ This configuration of the civil society argument was originally developed to explain democratization, but it has turned out to have significant implications for welfare state development in the global periphery. ${ }^{8}$ Strong civil society not only tames the state under former authoritarian legacies by installing democratic norms, rules, conventions, and personnel, but it also provides more favorable environments for the self-organization and mobilization of the subordinate class. As a universal welfare state requires "community-based solidarity (the moral economy)" to "scale up" to "societal solidarity (the public moral economy)," it is necessary to have strong democratic states with densely developed civil society in order to build a social democratic welfare state in an ideal sense. The explanatory model of this study starts from exactly this point: what if the scaling-up channeling efforts of community-based solidarity to the political arena is disconnected somewhere or disjointed for some structural reasons? What if influential political, civic, and economic elites maintain their own nexus but are disarticulated, that is, separated, from the community-based solidarity? Would their strategic choices still be guided by the principle of the moral economy, or would they be guided instead by some other factor or interest?

In order to answer these questions, under this configuration of civil society tradition, I bring in two less-explored or unexplored factors in accounting for the development or retrenchment of welfare states in developing countries: (1) cohesiveness of formal-sector organizations including interclass solidarity between the working class and other classes such as the urban middle classes (coalition among labor-related organizational units) and (2) the embeddedness of formal-sector organizations in the informal civic sphere. I propose that the differently configured coalitions and interorganizational structures among political parties, labor unions, and wider civil society formulate divergent welfare regimes and variations in welfare generosity in the four developing countries. In discussing positive cases, namely, Brazil and South Korea, I highlight the importance of the social embeddedness of formal politics in promoting welfare states. In discussing a negative case (Argentina) and a more moderate case (Taiwan), I explore how leaders of formal organizations disarticulated from civil society eventually

\footnotetext{
${ }^{6}$ Ruschemeyer, Stephens, and Stephens 1992.

${ }^{7}$ Collier and Collier 1991.

${ }^{8}$ Sandbrook et al. 2007.

${ }^{9}$ Sandbrook et al. 2007, 185.
} 
pursue either the radical retrenchment or the unexpected expansion of welfare states for their own survival.

I begin by building a theoretical framework that considers the notions of embedded cohesiveness and disarticulated cohesiveness, as well as their roles in accounting for variations in the politics of expansion and retrenchment of welfare states in the four developing societies under consideration here. Utilizing network analysis of comembership data, ${ }^{10} \mathrm{I}$ explore the associational structures of these four countries and build a causal framework to explain the effects of organizational configurations of formal and informal civic spheres on the politics of welfare states. Detailed comparative/historical case studies in combination with the results from formal network analysis, which I call "networkinformed case studies," will jointly account for the politics of social protection in four recently democratized developing countries.

\section{The Cohesiveness of a Labor-Based Formal Sector and Welfare Politics}

In examining the development of welfare states, this article focuses on the role of formal organizations, especially their interorganizational ties and linkages to larger informal civic networks. It distinguishes between the "formal institutional sphere" and the "informal civic sphere." The formal institutional sphere includes political parties, labor unions, and professional associations, each of which plays its distinctive roles in channeling group interests in the form of formulating and negotiating policy agendas as well as electoral bargaining. These associations are formal organizations, in the sense that they have established bureaucratic structures in which organizational goals, tasks, and agendas are formally codified in core members' routines, activities, and their interactions with outside worlds. The institutionalization of organizational routines is internally stipulated as each organization's rules while externally governed by laws. ${ }^{11}$

Informal civic organizations include churches and cultural activity groups such as singing groups, book clubs, charity associations, and sports clubs. They are the most informal, not (or not yet) politicized, relatively ideology-free or interest-free spaces between the state and family (or individuals). They are the civic space most distant from modern bureaucratized state institutions and interest-based organizations,

\footnotetext{
${ }^{10}$ Breiger 1974.

${ }^{11}$ Aldrich and Ruef 2006; Scott 2008.
} 
and they are the closest to informal, private, local community, and family lives. Putnam hoped to preserve this space against modernization and urbanization as the last resort for fostering citizens' civic and political efficacy. ${ }^{12}$ Habermas also claimed that the "lifeworld" embracing this informal civic sphere as a reservoir of "communicative reason" should be defended against the colonizing power of modern bureaucratic systems. ${ }^{13}$

Figure 1 displays the specific organizational linkages (solid lines) involving the cohesiveness of the formal sector. I initially define the cohesiveness of the formal civic sphere as the organizational linkages among the three key formal organizations. ${ }^{14}$ First, the linkage between political parties and labor unions represents traditional social democratic, labor-based power resources. ${ }^{15}$ The linkage "articulates class interests and mobilizes members into (collective) political action." ${ }^{16}$ As this linkage becomes stronger, the demand of the working classes for protection of their income and jobs will be more effectively channeled through party structures. In other words, unions' approval or disapproval is essential for the legislative passage of specific reform programs for either the expansion or the retrenchment of social policies.

Second, the linkage between labor unions and professional associations represents cross-class organizational coalitions between the working and middle classes. There are many historical incidences and theories demonstrating that strong working- and middle-class coalitions are more conducive to implementing and sustaining universal social policies. Historically, coalition building was one of the main

\footnotetext{
${ }^{12}$ Putnam 1993; Putnam 2000.

${ }^{13}$ Habermas 1984; Habermas 1987. Classifying new social movement associations such as environmental or human rights groups as either of these two types is ambiguous, because they often intrude into the realms of the formal sphere for promoting their agendas, by using divergent repertoires from protesting to lobbying. (Habermas himself recognized that new social movements emerge exactly between the system and lifeworld.) As environmental associations in developing countries have rarely advanced to the status of formal political stakeholders such as unions and parties, however, we initially classify them as informal civic organizations. In the empirical analyses, we also attempted to classify them the other way (as formal-sector organizations), but different classifications of these NSMs did not change the results reported in the main text.

${ }^{14}$ The measure of cohesiveness is calculated as follows:

Cohesiveness of Formal Organizational Sphere $=\sum\left(C M_{i, j}\right) / M(\min )_{u, p a, p r}$

$$
(\mathrm{i} \neq \mathrm{j}, \mathrm{i}, \mathrm{j}=\text { any of formal organizations), }
$$
}

where the numerator denotes the sum of all comemberships among three formal organizations, political parties, unions, and professional associations, and the denominator, $M(\min )_{u, p a, p r}$, denotes the membership count of three key formal organizations, excluding any redundant memberships. I decided to assign equal weight to the three linkages among the three organizations, but Tables 3 and 4 report and discuss party and union's cohesiveness (and embeddedness) separately in greater detail. See Appendix 2 for further explanations regarding the measurement of interorganizational ties in a comembership matrix.

${ }^{15}$ Stephens 1979; Korpi 1983; Esping-Andersen 1985.

${ }^{16}$ Huber and Stephens 2001, 18. 


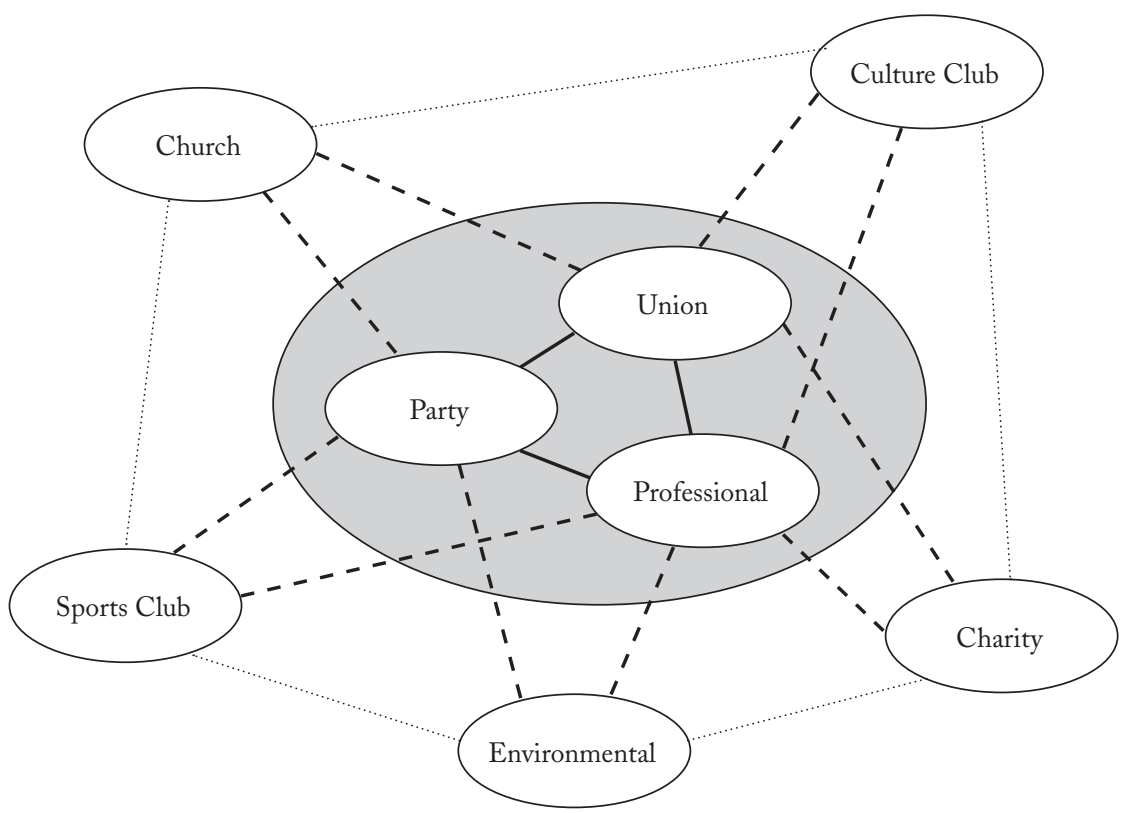

Formal-Sector Organizations

Interorganizational Ties within Formal Sector (Ingredients of Cohesiveness)

- - - - - Interorganizational Ties between Formal Sector and Informal Civic Sphere (Ingredients of Embeddedness)

Interorganizational Ties among Informal Civic Organizations (Not used in this study)

\section{FiguRE 1}

Illustration of Cohesiveness And EmbedDedness in Formal AND INFORMAL Civic SECTORS

driving forces behind welfare state development. The celebrated social democratic welfare states were indeed built upon the cross-class political alliance of working-class movements and farmer organizations. ${ }^{17}$ As the new middle classes emerged in postindustrial economy, Nordic social democracy anchored its political base on a new coalition of the

${ }^{17}$ Esping-Andersen 1990. 
working classes and the emerging middle classes. Often, the middleclass segments of the population played a key role in creating social democracy and universal welfare states. ${ }^{18}$ The most stable and successful welfare programs were the ones that served the interests of the middle classes. In other words, creating political coalitions that embrace not only the demands of the needy and the poor but also the demands of the middle classes for insuring themselves from certain risks will be the most effective strategy for building universal welfare states. In such societies, with their strong linkages between unions and professional associations, the middle classes are likely to have greater sympathy for the idea of pursuing and defending universal social policies.

Finally, even though it is unclear whether linkages between middleclass-oriented professional associations and political parties necessarily defend or promote "universal" social policies, professional organizations in advanced industrial democracies have historically played positive roles in claiming welfare state benefits for the middle classes and in defending professional interests in the provision of welfare state services. ${ }^{19} \mathrm{In}$ addition, some professional associations, such as lawyers and professors, have played significant roles in introducing social policies in some developing countries (for example, South Korea and Taiwan) by formulating advocacy coalitions for the legislation of specific social policies. ${ }^{20}$

In sum, the labor-based organizational ties among these three formal organizations summarize a society's general capacity to represent the institutionalized channeling processes of class-based interests into political arenas. I initially concur with the former power-resource and coalition-building approach to welfare states in my conceptualization of the cohesiveness of the formal sector, but this study also develops a different argument from conventional power-resource theory. It instead takes into account the "social embeddedness" ${ }^{21}$ of formal politics. In developing countries in which a larger segment of the rural and urban poor is in the informal sector and in which the size of the organized working class is much smaller than in advanced industrial economies, the politics of cohesiveness along the lines of trade unions and political parties do not always function for the development of universal welfare states. Rather, they often end up with populist corporatism through co-optation of the working class by populist elites. ${ }^{22}$

\footnotetext{
${ }^{18}$ Luebbert 1991; Baldwin 1990.

${ }^{19}$ Baldwin 1990; Huber and Stephens 2001.

${ }^{20}$ Kwon 2003; Wong 2004.

${ }^{21}$ Granovetter 1985.

${ }^{22}$ Malloy 1979; Lee 2005; Lee 2007.
} 
Without their linkages to the wider civil society, unbridled formal organizations and their leaders may operate on their own, for their own survival and interests.

\section{Social Embeddedness of Formal-Sector Organizations ANd Welfare Politics}

In this section, I contend that the capacity for social policy formulation of a labor-based formal sector is based not only on its cohesiveness but also on its degree of "embeddedness" 23 in the informal civic sphere (see the dashed lines between three formal and five informal civic organizations in Figure 1) ${ }^{24}$ I propose that the embeddedness of a specific formal organizational structure in the informal civic sphere addresses two fundamental issues in democratic class mobilization: first, in societies in which formal interest bargaining structure is closely connected to informal civic lives, citizens will build stronger "trust" 25 with formalsector organizations in charge of interest channeling and bargaining. Second, in those countries with stronger organizational linkages between formal and informal civic associations, politicians will be more reliably responsive to their constituents' demands for maintaining or expanding universal social protection, as they not only become more worried about potential punishment by voters in future electoral cycles but also become increasingly engaged in the informal deliberation of a specific policy in the sea of public opinion. Conversely, in societies with weak organizational and institutionalized connections between the formal and informal spheres, neither parties nor unions are committed to sponsoring their deeper electoral or organizational bases, and thus they may, if necessary, seek to cultivate new constituencies for electoral survival.

The first argument is based on the long tradition of sociological literature concerning the importance of social relations in the creation of economic trust; ${ }^{26}$ it then focuses on the role of social relations in

${ }^{23}$ Granovetter 1985; Portes and Sensenbrenner 1993.

${ }^{24}$ The measure of embeddedness is calculated as follows:

Embeddedness of Formal Sphere $=\Sigma\left(C M_{i, k}\right) / M(\min )_{u, p a, p r}$

( $i \neq k, i=$ any of formal organizations, and $\mathrm{k}=$ any of nonformal civic associations), where the numerator denotes the sum of all comembership counts between formal organizations and informal civic associations. Informal civic associations (k) include churches, cultural clubs, environmental associations, sport clubs, and charity clubs. Refer to Appendix 2 for detailed explanations of the measurement of cohesiveness and embeddedness of formal organizational sphere. See Table 2 for calculated scores of cohesiveness and embeddedness for each country.

${ }^{25}$ Granovetter 1985; Coleman 1990.

${ }^{26}$ Granovetter 1985; Granovetter 2002. 


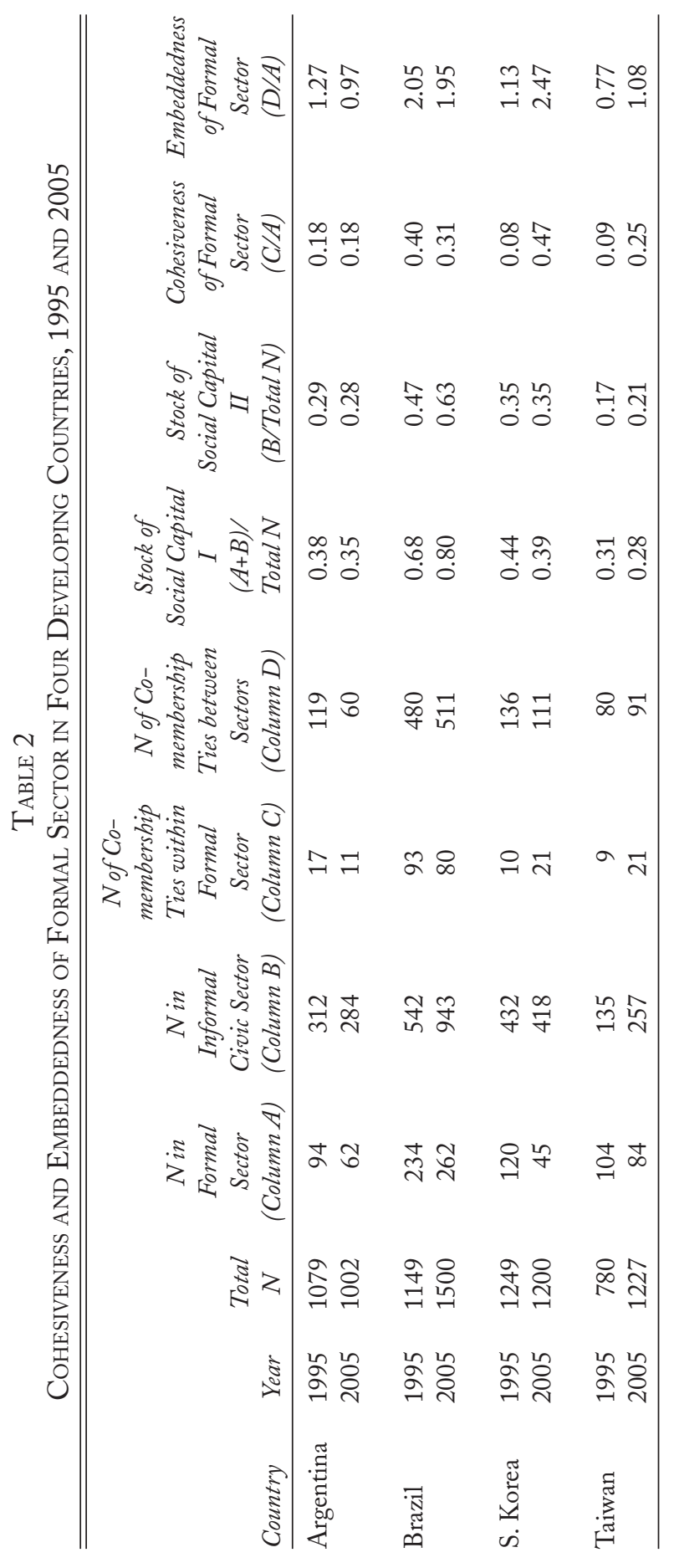


formulating political trust between voters and formal organizations (or their leaders) and building/retrenching welfare states.

Provided that "trust consists of placing valued outcomes at risk of other's malfeasance, mistakes, or failures," ${ }^{27}$ I may conceive of organizational linkages between voters in informal sectors and leaders in formal organizations as representative of the strength of political trust between them. Voters take the risk of supporting their representatives in these formal organizations without any guarantee of benefits through generous social protection. They indeed risk being ignored after every electoral cycle. Leaders of those formal sectors, especially party and union leaders, are also at risk of losing votes even after they have provided their constituents with what they promised. Voters may not be patient enough to wait to see the effects of social policy implementation, the impact of which may be visible primarily only in the long term, whereas, by contrast, electoral and membership dues are apparent in the short term. Voters may switch their support to competitors with similar, but seemingly more attractive policy repertoires (for example, direct cash transfers rather than institutional insurance programs). Therefore, both voters' support and policy delivery by leaders of formal organizations increase one's vulnerability to the other, as one party's behavior is potentially "not under [the] control" 28 of the other.

Under this circumstance, voters' actions will be based upon their preference for organizations and leaders whose reputations are familiar to them or are at least known from indirect referrals obtained through relevant networks. When citizens are better connected with leaders of the formal-sector organizations, they will be exposed to a higher volume of information exchanges and will therefore construct a more correct assessment of the trustworthiness, reliability, effectiveness, and relevance of organizational leaders and their policy platforms. I generally assume that prolonged interorganizational ties over time will facilitate not only these information exchanges and assessments but also eventual trust of leaders (insofar as those who have sacrificed trust based on information exchanges would sever ties). ${ }^{29}$

The second argument is built upon this trust relationship between leaders of formal organizations and citizens in both the formal and the

\footnotetext{
${ }^{27}$ Tilly 2005, 12.

${ }^{28}$ Kollock 1994.

${ }^{29} \mathrm{I}$ am aware that there exists a considerable amount of literature in which this political leader-voter relationship is depicted as a "patron-client" relationship (Kitschelt and Wilkinson 2007; Stokes 2007). Note, however, that the "trust relationship" based on formal-informal associational linkages discussed in this study should be fundamentally distinguished from the relationship of "a repeated game between voters and parties embedded in social networks"(Stokes 2007, 615). Such clientelistic relationships
} 
informal civic spheres. It emphasizes the role of social relations in constraining and limiting formal politics: it not only allows a partisan formal sector based on labor to advance more progressive egalitarian agendas in welfare politics but also sets a limit on retrenchment in periods of economic crisis. On the one hand, the labor-based formal sector deeply embedded in informal sectors is representative of participatory institutional politics. Those labor-based party or union leaders anchored in informal civic associations are more likely to have initially evolved from the (Tocquevillian) local community as community organizers, who are distinct from the labor aristocracy and machine politicians. Their collective identities are more likely to originate in residential neighborhoods, as exemplified by the community-based mobilization of the 1871 Paris Commune. ${ }^{30}$ They are more likely to care about the general interests of people of diverse class origins with whom they have interacted in local churches, cultural and sport clubs, and town hall meetings. Therefore, embedded formal-sector leaders are more likely to employ policies that will enhance their "social legitimacy" 1 and build "social solidarity" by serving a wide range of social forces.

On the other hand, the embeddedness of the formal sector in the informal sector may also represent the degree or strength of cognitive "social learning" processes by which political actors reach the "resolution of competing claims" through the exchange of ideas and perceptions. ${ }^{32}$ The aforementioned "information exchange" and "assessment of trustworthiness of leaders' platforms" are more likely to abound in the intersections of formal and informal civic sectors. Formal-sector leaders embedded in informal civic spheres will therefore have a greater chance to formulate public opinions, discussions, and debates, as well as, further, to craft negotiations and prebargaining at these intersections of the formal and informal civic spheres. Formal-sector leaders with high embeddednesss are thus likely to be representative of already negotiated interests and opinions as a form of civic consensus and therefore to be able to channel universal and "programmatic" 33 voices to political arenas. Alternatively, embedded formal-sector leaders are

\footnotetext{
are more personalistic, nonassociational, and hierarchical networks between unconstrained party brokers and isolated local voters who lack other organizational resources. In a sense, clientelisic brokerage may abound in a society in which formal-sector leaders are not constrained by local civic associations. In this sense, Kitschelt and Wilkinson's "programmatic, indirect exchange relationships" are more likely to emerge in a society with embedded cohesiveness, while "clientelistic direct exchanges" are more prevalent when formal-sector leaders are disarticulated from informal civic associations.

${ }^{30}$ Gould 1995.

${ }^{31}$ Suchman 1995.

${ }^{32}$ Chalmers, Martin, and Piester 1998, 565.

${ }^{33}$ Kitschelt and Wilkinson 2007.
} 
likely to learn how to articulate interests and opinions of different social origins and then to mobilize and convey them into political arenas, utilizing their unique structural positions as "brokers" 34 between the formal and informal civic sectors. Accordingly, embedded formal-sector leaders, as more democratic and programmatic brokers, are more likely to have greater political skills for organizing a wide array of social forces to formulate "cross-class alliances."

In addition, embedded formal-sector leaders will resist and challenge the strategic decisions of charismatic or technocratic formal-sector leaders. Thus, even when confronting national debt or financial crises, embedded leaders do not pursue radical market-oriented reform of the existing social welfare system, out of concern for the detrimental effects that such neoliberal reforms may exert not only on their core constituencies but also on surrounding communities. Instead, they may seek a moderate reform for minimum-level survival in international markets combined with another generous package of social protection for those most vulnerable during the course of the reform project. Because of their origins in local communities and their ongoing ties and relationship of trust with them, they may be able to persuade grassroots civil societies to tolerate the reforms necessary for the survival of the entire nation in the global market (not merely for their own survival), while simultaneously taking care of those most vulnerable to structural reforms.

By contrast, formal-sector leaders who are not constrained by preexisting attachments to the informal civic sphere may be freer to risk implementing more radical market-oriented reforms. Although they may lose their existing constituency, they may expect to benefit by gaining new constituencies. The formal-sector leaders without connections to the informal sectors may be lacking in institutional and ideological commitments to their old constituency, the poor, the working class, and some liberal segments of the middle class. They will then be more concerned about their own survival in an election than about the welfare of the people they have represented. Formal-sector leaders, that is, may abandon their traditional electoral base regardless of political ideology if they can attract new supporters. Thus, in the name of political survival, formal-sector leaders with traditional right-wing tendencies but without solid embeddedness in the informal civic sphere could even resort to left-wing populist mobilization strategies, just as those with past left-wing tendencies might suddenly pursue radical marketoriented reform of the public sector.

${ }^{34}$ Gould 1989; Gould and Fernandez 1989. 
Figure 2 summarizes the arguments I have made, including two explanatory factors, the cohesiveness and the embeddedness of the formal organizational sector. ${ }^{35}$ When the formal-sector organizations are disarticulated from the informal civic sphere, incumbent party leaders may boldly attempt to adopt reform projects developed by other parties or opposite platforms, as shown in the combination of strong cohesiveness and weak embeddedness. This opportunistic strategy is deemed realistic when party leaders assume that constituents of other political camps are not loyal to their opponents (or other political camps are not cohesive and strong enough to retain their constituents), perceive that new policy platforms could attract more votes than the old platform, and, finally, find that their ideological commitments to their traditional electoral base are out of date, due to industrial and occupational transformation, ${ }^{36}$ and therefore no longer needed for their survival.

However, when the leaders of the (labor-based) formal sector are closely linked to each other and simultaneously deeply embedded in the civic activities of the local community, they will consciously channel a wide range of working-class and middle-class demands into the political bargaining tables among formal-sector organizations, and promote more universal and programmatic social policies to sponsor broader communities in addition to their constituents. In the same vein, leaders of the (labor-based) formal sector with strong cohesiveness and embeddedness will vehemently resist the pressures of neoliberal reform agendas from right-wing parties, government technocrats, and foreign agencies such as the IMF and the World Bank.

\section{Case Studies I: Argentina vs. Brazil}

The case of Argentina is emblematic of relatively strong cohesiveness and weak embeddedness of the formal sector. President Carlos Menem's radical neoliberal reform of public sector and social welfare programs, especially concerning pensions, in the 1990s, along with a striking transformation of the PJ (the Justicialist Party), led to a huge political and electoral success. Menem's reform strategy fundamentally

${ }^{35}$ Collier and colleagues' CIRELA project (e.g., Handlin and Collier 2009) also attempts to develop a theoretical framework that utilizes these two dimensions in similar ways (in their terminology, Up-hub and A-net, denoting union-party linkage and associational networks, respectively). However, there are fundamental differences between their approach and this study: (1) they do not delve into the interactions between the two dimensions; (2) they do not theorize associational embeddedness as "a (political) trust relationship," as I do here; and (3) they do not investigate the causal impacts of associational structures on social policy outcomes.

${ }^{36}$ Burgess and Levitsky 2003. 


\section{Embeddedness of Formal sector}

Weak

Strong

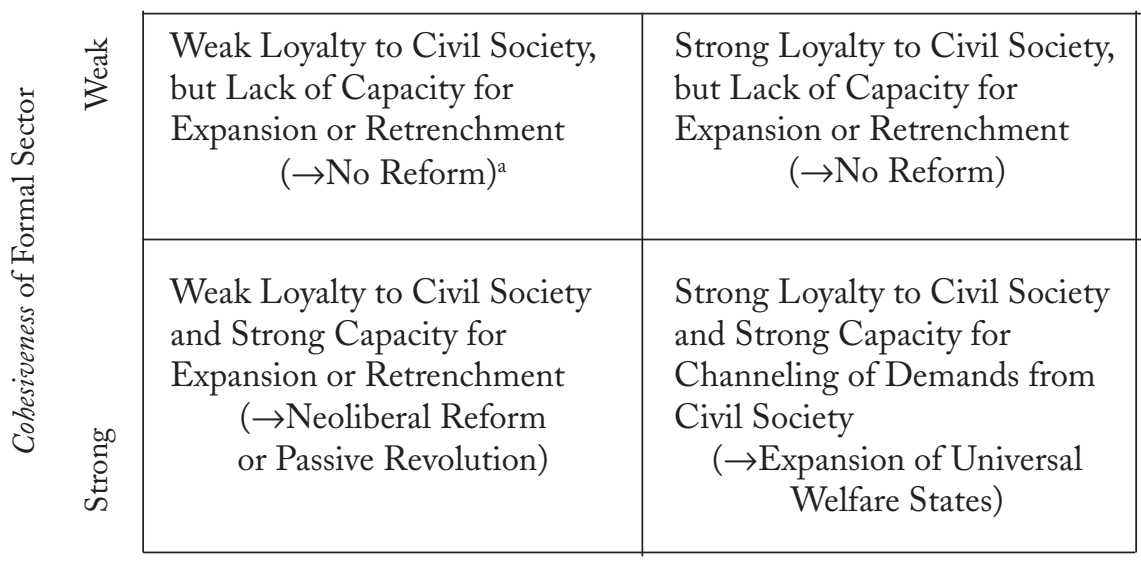

Figure 2

Combinational Spaces of Cohesiveness and Embeddedness of FORMAL SECTOR $^{\mathrm{a}}$

a I initially assume that there will be no reform initiative under weak cohesiveness and weak embeddedness but allow an exception in Figure 7 and related discussions.

transformed the Argentine economy from a protected market with a large public sector to a more market-oriented open economy. Menem and the PJ's neoliberal reform projects of the public sector were all the more striking because the PJ was a representative left-wing, labor-based party that had played a central role in creating modern Argentina's relatively generous welfare programs. ${ }^{37}$

A central argument of this study is that the relatively strong cohesiveness and weak embeddedness of formal-sector associations allowed Menem and the PJ to implement such radical neoliberal reform of the public sector. In 1995, about the time when Menem had just embarked upon pension reform, ${ }^{38}$ labor unions still maintained fairly close relationships with political parties, as shown in Table 3. The linkages of Argentina's parties with unions and professional associations

\footnotetext{
${ }^{37}$ Brooks 2009; Levitsky 2003.

${ }^{38}$ It started in 1994, but several ensuing adjustments and legislations were made in 1999, 2004, and 2008.
} 
TABLE 3

Unions and Parties' Interorganizational Ties Within and outside Formal Sector in Four Developing Countries, 1995 and 2005

\begin{tabular}{|c|c|c|c|c|c|}
\hline & Year & $\begin{array}{l}\text { Parties'Ties }^{a} \\
\text { within Formal } \\
\text { Sector } \\
\text { N of Party } \\
\text { Members } \\
\text { (Column A) }\end{array}$ & $\begin{array}{l}\text { Parties'Ties } \\
\text { outside Formal } \\
\text { Sector } \\
\text { N of Party } \\
\text { Members } \\
\text { (Column B) }\end{array}$ & $\begin{array}{c}\text { Unions'Ties }^{b} \\
\text { within Formal } \\
\text { Sector } \\
\text { NNof Union } \\
\text { Members } \\
\text { (Column C) }\end{array}$ & $\begin{array}{c}\text { Unions'Ties } \\
\text { outside Formal } \\
\text { Sector } \\
\text { Nof Union } \\
\text { Members } \\
\text { (Column D) }\end{array}$ \\
\hline \multirow{2}{*}{ Argentina } & 1995 & 0.32 & 0.85 & 0.58 & 1.37 \\
\hline & 2005 & 0.33 & 0.63 & 0.57 & 0.57 \\
\hline \multirow[t]{2}{*}{ Brazil } & 1995 & 0.51 & 1.46 & 0.65 & 1.44 \\
\hline & 2005 & 0.56 & 1.53 & 0.45 & 1.33 \\
\hline \multirow[t]{2}{*}{ S. Korea } & 1995 & 0.23 & 1.00 & 0.25 & 1.13 \\
\hline & 2005 & 1.00 & 2.08 & 0.83 & 2.00 \\
\hline \multirow[t]{2}{*}{ Taiwan } & 1995 & 0.23 & 0.92 & 0.12 & 0.55 \\
\hline & 2005 & 0.38 & 0.95 & 0.50 & 0.68 \\
\hline
\end{tabular}

\footnotetext{
a Parties' ties include comembership values (1) between party and union and (2) between party and professional association.

b Unions' ties include comembership values (1) between union and party and (2) between union and professional association.
}

were moderately strong compared with the situation in other countries. At the same time, however, the political parties' linkages to nonformal civic organizations in Argentina were much lower than those in other countries.

The disarticulated formal sector-characterized by weak ties between the formal sector and the informal civic sphere, in contrast to stable, relatively durable ties within the formal sector-gave Menem and the PJ sufficient room to cultivate new electoral coalitions around newly emerging service sectors and those elements of the poor urban sectors that were still loyal to the PJ. ${ }^{39}$ Some union leaders of the CGT (General Confederation of Labor) also remained with Menem as the PJ's constituents and clients, receiving the rights to create and run their own health care programs. ${ }^{40}$ Some unions' cohesive support for $\mathrm{Me}-$ nem, his finance technocrats, and the PJ played a critical role in the

\footnotetext{
${ }^{39}$ See Auyero 1999 for the form and functions of Peronist broker-client networks in urban slums.

${ }^{40}$ Madrid 2003; Murillo 2001.
} 
passage of pension privatization in the legislature, although the majority of unions remained opposed to the reform drive. ${ }^{41}$

As a result of a decade of radical market-based reforms, however, many union organizations increasingly cut their ties with the PJ. ${ }^{42}$ In other words, the formerly labor-based PJ's strong cohesiveness in the formal sector and weak embeddedness in informal civic associations eventually weakened its own cohesive ties with traditional alliesunions - in the formal sector. This gradual erosion of the PJ's organizational base within the formal sector was driven mainly by union leaders who could not sustain grassroots-level anger at Menem's retrenchment drive. Menem's technocrats and the PJ legislators kept revising the compromised restructuring proposals by cutting (and eventually eliminating) the guaranteed minimum pension amount, lowering replacement rates, and setting an upper limit on pension benefits. ${ }^{43}$ Increasingly more union organizations and members became disenchanted and enraged by Menem's continued retrenchment moves in times of repeated economic crises.

In the end, the PJ's radical market reforms based on its cohesiveness led to a fundamental dismantling of its traditional mass labor-party structure, which had been built on close interorganizational networks between the PJ and labor unions. There was a dramatic breakdown of longtime traditions - of union members' participation in the PJ's political activities, of PJ leaders' political careers as union members, ${ }^{44}$ and of union leaders' connections with the informal civic sphere. As a result, labor unions' embeddedness plummeted for a decade, scoring 0.57 in 2005, the lowest among the four case countries.

More specifically, Table 4 shows that, in 1995, 20 percent of the PJ members had ties to labor unions and professional associations, but in 2005, strikingly, none of the PJ members kept up ties to other formalsector associations (zero out of ten), while 36 percent of non-PJ members (five out of fourteen) ${ }^{45}$ were coaffiliated with unions in 2005. In

${ }^{41}$ Roberts 2006.

${ }^{42}$ This "reciprocal, feedback effect of neoliberal reform" on cohesiveness suggests that disarticulated cohesiveness may not necessarily persist in the long term, and therefore transformative politics by the PJ were destined to oscillate between populist co-optation (of the working class) and neoliberal reform (targeting the middle class), depending upon economic and electoral cycles. Indeed, the PJ reinforced the public component in the pension system in 2007 (Brooks 2009) to win back the disenchanted former party base.

${ }^{43}$ Kay 2000; Haggard and Kaufman 2009.

${ }^{44}$ Levitsky 2003.

${ }^{45}$ The interpretation of these findings for Argentina in Table 4 (also those for Taiwan) requires some caveats, as they are based on a very small number of ties. However, despite its limitation, the PJ's decline in its comembership with unions is too obvious. 
TABLE 4

Parties' Interorganizational Ties With Unions and Informal Civic Sector, By Partisanships

\begin{tabular}{|c|c|c|c|c|c|}
\hline \multirow{2}{*}{$\frac{\text { Country }}{\text { Argentina }}$} & \multirow{2}{*}{$\begin{array}{l}\text { Year } \\
1995 \\
2005\end{array}$} & \multicolumn{2}{|c|}{$\begin{array}{c}\text { Party-Union Ties } \\
\text { N of Party Members } \\
\text { (Column A) }\end{array}$} & \multicolumn{2}{|c|}{$\begin{array}{c}\text { Party's Ties outside } \\
\text { Formal Civic Sector } \\
\text { /N of Party Members } \\
\text { (Column B) }\end{array}$} \\
\hline & & $\begin{array}{c}0.20(\mathrm{PJ}) \\
0(\mathrm{PJ})\end{array}$ & $\begin{array}{l}0.11 \text { (non-PJ) } \\
0.36 \text { (non-PJ) }\end{array}$ & $\begin{array}{l}0.87(\mathrm{PJ}) \\
0.50(\mathrm{PJ})\end{array}$ & $\begin{array}{l}0.84 \text { (non-PJ) } \\
0.43 \text { (non-PJ) }\end{array}$ \\
\hline Brazil & $\begin{array}{l}1995 \\
2005\end{array}$ & $\begin{array}{l}0.41(\mathrm{PT}) \\
0.29(\mathrm{PT})\end{array}$ & $\begin{array}{l}0.21(\text { non-PT }) \\
0.28(\text { non-PT })\end{array}$ & $\begin{array}{l}1.46(\mathrm{PT}) \\
1.71(\mathrm{PT})\end{array}$ & $\begin{array}{l}1.46 \text { (non-PT) } \\
1.37 \text { (non-PT) }\end{array}$ \\
\hline S. Korea & $\begin{array}{l}1995 \\
2005\end{array}$ & no $p$ & sanship informat & available for & Korea \\
\hline Taiwan & $\begin{array}{l}1995 \\
2005\end{array}$ & $\begin{array}{l}0.18 \text { (Кмт) } \\
0.46 \text { (КМТ) }\end{array}$ & $\begin{array}{l}0.22 \text { (non-KMT) } \\
0.13 \text { (non-KMT) }\end{array}$ & $\begin{array}{l}0.53 \text { (КМт) } \\
0.54 \text { (КМТ) }\end{array}$ & $\begin{array}{l}1.67 \text { (non-КмТ) } \\
1.63 \text { (non-КМт) }\end{array}$ \\
\hline
\end{tabular}

short, after more than a decade of neoliberal reform, union leaders and members not only completely cut ties with the PJ but also had fewer ties with informal civic associations. One possible explanation for this reduced union embeddedness may be that the unions' break with the PJ also led them to lose their mediating position between the PJ and the informal civic sphere. It is not a coincidence that Argentine labor movements, being isolated from both the PJ and civic communities, increasingly show segmented, uncontrolled militancy about wage demands at the firm or industry level, rather than coordinated electoral demands for social welfare. ${ }^{46}$ These characteristics of Argentine formal and informal civic spheres are clearly illustrated in Figure 3, in which both union and party are sparsely connected to other nonformal civic associations. ${ }^{47}$

To sum up, the departure of a labor-based party from its traditional base of support, as indicated by radical retrenchment of state sectors and state-funded social programs, could be attributed more generally to the lack of social embeddedness of Argentine political parties, especially the PJ. In addition, this Argentine case illustrates how a loosely

\footnotetext{
${ }^{46}$ Etchemedy and Collier 2007.

${ }^{47}$ These results are consistent with Etchemendy and Collier's (2007) contrast of densely connected social movement unionism in Brazil and Peronist top-down, disconnected unionism in Argentina.
} 


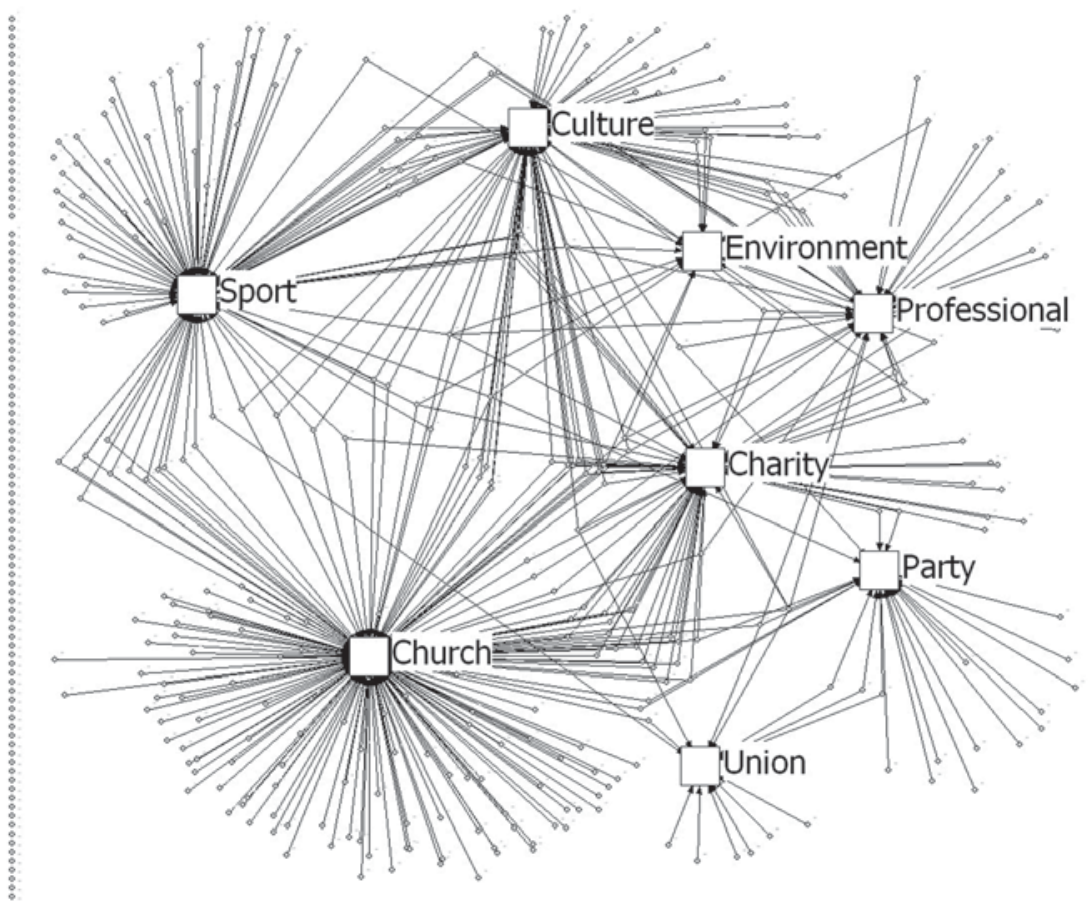

FIGURE 3

Associational Networks Based on Comembership Data for Argentina, $2005^{\mathrm{a}}$

\footnotetext{
${ }^{\text {a }}$ The dots along the left-hand side are respondents without any associational membership. This holds for Figures 3-6.
}

linked political organization could easily detach itself from both formal-sector allies and its community-based informal civic associations. The transformative move toward market reforms by the PJ in initial alliance with unions eventually led to its alienation from its traditional allies, the unions, and consequently, to the demise of labor-based social solidarity.

Brazil, with its impressive record of growth and reduction in poverty, is the most exemplary case of participatory democracy in recent decades. Most importantly, in contrast to other countries in Latin America, it has successfully resisted market-reform pressure on both the public sector and social policies. I argue that the political and economic success story of contemporary Brazil could be an outcome of the strong cohesiveness and strong embeddedness of the formal sector. Figure 4 shows that unions, parties, and professional associations not 


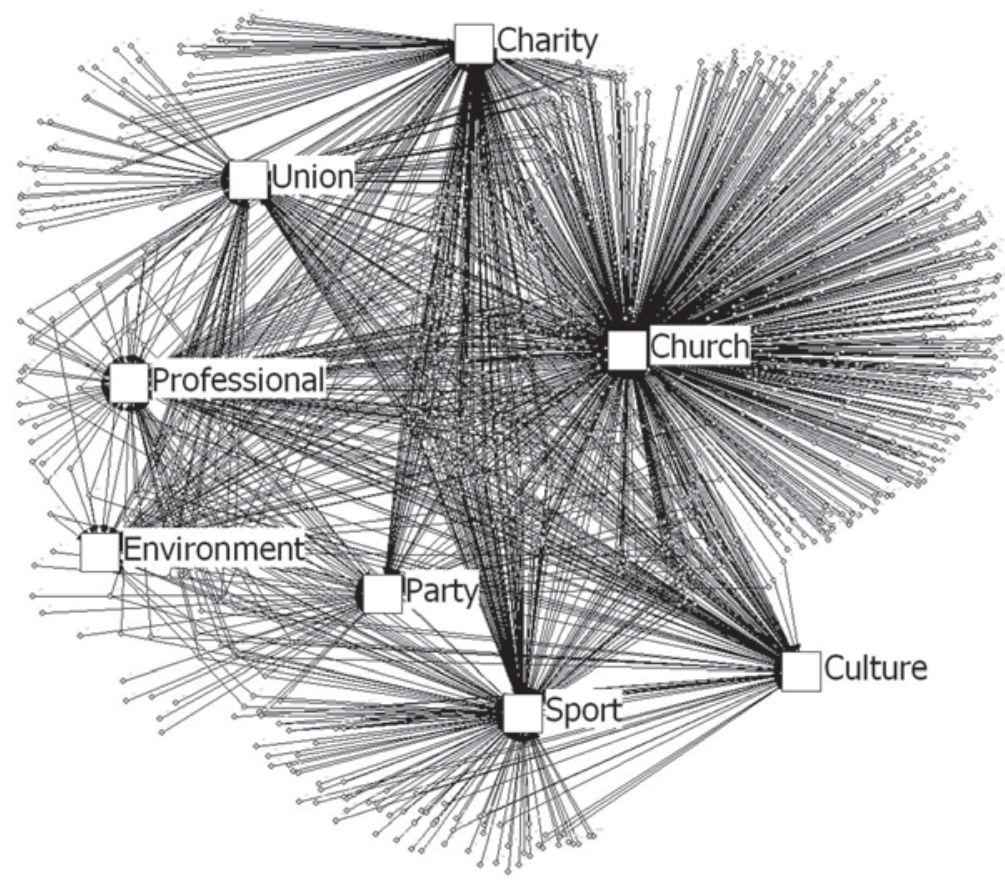

Figure 4

Associational Networks Based on Comembership Data for Brazil, 2005

only are densely connected to each other but are also deeply embedded in informal civic associations, such as churches, cultural gatherings and clubs, and charity associations. Table 3 shows that labor unions' cohesiveness and embeddedness decreased slightly from 1995 to 2005 but that political parties' linkages with formal and informal civic associations have been stable with a slight upward trend. Compared with Argentina, Brazil's union and party linkages within the formal sector are not impressively higher, but their connections to informal civic lives are vast: the embeddedness of Brazilian formal organizations in the informal civic sphere is roughly two times higher than that of the Argentine formal sector (see Table 2).

Based on the strong embeddedness of the formal sector in informal civic organizations, both center-right parties and labor-based parties have been relatively committed to the demands of the poor and the working classes. Party and union leaders embedded in citizens' every- 
day lives through religious and cultural activities are less likely to embark on radical neoliberal reform paths, as Argentine and other Latin American organizational leaders did.

It is important to point out that recent policy adoption and implementation processes in Brazil are fundamentally different from market reforms in the the rest of Latin America. As the PT illustrates, many party and union leaders in Brazil came out of local, municipal-level community politics. ${ }^{48}$ As participatory budgeting movements in Porto Alegre and other Brazilian cities signify, ${ }^{49}$ local community politics at the state and municipal levels educate participatory publics and leaders, some of whom eventually rise to the top of national-level politics, as happened with Lula da Silva. They refuse to accept the idea that elite politicians mediate and represent the demands of unions or social movements in conventional representative democracy. They desire to eliminate the dichotomy of government versus movements and thus to build the government from below via social movements. The refusal to permit a dichotomy between governments and movements allowed the PT to develop modes of close "organizational communication between politicians, party organs, and grassroots organizations." ${ }^{\text {0 } 0}$ This open communication mode initiated by community-oriented party leaders has enabled the PT to represent broader social bases beyond labor unions, and indeed has led wider publics of diverse class origins to support the labor-based party's local and central governance. The PT's local and central leaders have occupied the "bridging position" ${ }^{1}$ between the formal sector and the informal civic sphere. Such a structural position based on its origins in social movement and its communal leadership made it possible for PT municipal and federal candidates to succeed not only in electoral politics but also in participatory governance.

This grassroots institutional and movement-based mobilization of publics and leaders and the consequent political trust between formal party organs and informal grassroots organizations played decisive roles

\footnotetext{
${ }^{48}$ The Workers' Party has a very peculiar organizational structure and culture: it was established in 1980 by leaders of two workers' movements (Central Unica dos Trabalhadores [CUT] and Movimento dos Trabalhadores Rurais Sem Terra [MST]) and activists from the Catholic Church (if MST was officially founded later in 1984). CUT is a newly established, strong trade union confederation and MST is a nationwide landless workers' association. Both organizations share the same members and leaders with the PT, but the PT is not officially funded by these organizations. Rather, the progressive wing of the Catholic Church, being influenced by the critical pedagogy and the liberation theology of Paulo Freire (who joined the PT in 1980), has played a critical role in financially supporting the party and in culturally shaping the party's unorthodox and progressive ethic codes (for example, it approves gay and abortion rights) (Keck 1992; Branford and Kucinski 2003).

${ }^{49}$ Avritzer 2009; Baiocchi, Heller, and Silva 2011.

${ }^{50}$ Guidry 2003, 104.

${ }^{51}$ Mische 2008.
} 
in welfare politics. Under economic pressures (regarding the budget and debt crises) similar to Argentina's, Brazilian political leaders were reluctant to turn to economic technocrats. Both Cardoso (1994-2002) and Lula (2002-10) took the privatization path off the table, turning to more moderate reform paths by changing entitlement criteria, as the PT and its allied civil-society movement activists staunchly opposed any privatization plan. ${ }^{52}$ Eventually, the PT and its allies successfully defended the pension system without resorting to radical retrenchment.

Furthermore, they introduced Bolsa Familia, an innovative cashtransfer program conditional upon a child's regular school attendance and participation in vaccination programs, nutrition programs, and vocational training courses, ${ }^{53}$ by unifying several preexisting schemes of family allowance programs. ${ }^{54}$ In a society like Brazil, in which extreme poverty and inequality are prevalent and existing social insurance programs favor workers in the core industries and public sectors, implementing an effective social assistance program is as important as defending an existing social insurance program. Bolsa Familia has been so effective in fighting poverty that the World Bank praised it as the most efficiently targeted CCT scheme in Latin America. The universal delivery criteria and performance of the benefits are indicative of the commitment of embedded PT leaders to serving the poor in the urban and rural informal sector: 73 percent of the benefits are delivered to the poorest 20 percent of the population, and 94 percent are given to the lowest two quintiles. ${ }^{55}$ This Brazilian CCT case is impressively comparable to the Argentine case, in which a CCT program has been implemented on a similarly large scale, but the handouts in Argentina were delivered to loyal voters primarily through patronage party brokers' personalized, clientelistic social networks, ${ }^{56}$ with the result that only 32 percent of the handouts reached the poorest 20 percent. In short, Brazilian embedded formal-sector leaders are more likely to deliver their social policy benefits to a wider range of constituents beyond their partisan loyalists.

${ }^{52}$ Hunter 2010.

${ }^{53}$ Hall 2008; Lomeli 2008.

54 Studies focusing on the electoral institutions (Carey and Shugart 1994; Shugart and Carey 1992), party systems, and constitutional structures (Ames 2001; Mainwaring 1999) may contend that multiple veto points originating from fragmented party systems, undisciplined party leadership (which may be attributable to open-list PR), and federalism are responsible for the difficulty in effecting policy reforms in Brazil. However, these institutionalist perspectives are incapable of explaining the recent emergence of disciplined leadership and antipoverty policy reform efforts by the Workers' Party in Brazil.

${ }^{55}$ Hall 2008.

${ }^{56}$ Calvo and Murillo 2010; De La O 2011. 
Table 2 shows that formal-sector associations in Brazil are not comparable to those in other countries in terms of either their sizes or linkages. In 1995 the cohesiveness and embeddedness of formal-sector associations were nearly twice as large as those of Argentina. Furthermore, Brazilian political parties have maintained a very different structure of organizational linkages with unions and other informal civic organizations, compared with their Argentine counterparts. In Table 3, both parties' and unions' linkages within and outside the formal civic sector are the highest among the four countries in 1995, and the second highest in 2005. In Table 4 both PT and non- PT have maintained relatively close linkages to unions within the formal sector. As compared with parties in Argentina, the Brazilian parties' embeddedness in the informal civic sphere has remained much higher. Within Brazil, these differences in the strength of union-party linkages between the PT and non- PT parties are not noticeably large ( 0.29 versus 0.28 in 2005), but the PT moderately increased its embeddedness in the wider nonformal civic community (1.71 compared with 1.46). Overall, Brazilian party leaders have maintained relatively stable interorganizational linkages within the formal sector and with the informal civic sector, and, despite the pressures from debt and balance-of-payment crises, they not only resisted neoliberal market-oriented reform pressures on their social insurance system but also successfully extended their universal poverty alleviation program to eligible populations on an unprecedented scale.

To summarize, the Brazilian case suggests that the embedded cohesiveness of participatory mobilization is critical for deterring and moderating retrenchment pressures on social policies under economic crisis. Party and union leaders embedded in social-movement and community associations did not choose to bandwagon successful market-oriented reform paths in neighboring countries, but carefully created and utilized space for maneuver among market forces composed of international and domestic capital, labor unions and popular movement organizations, constituents with different interests, and other stakeholders.

\section{Case Studies II: Taiwan versus South Korea}

Taiwan and South Korea appear to have followed very similar trajectories in their welfare state development. After the transitions to democracy in the late 1980s, both countries achieved the dramatic expansion of their social policy regimes. Not only did they reshape health insurance to cover nearly the entire population with a unified singlepillar system, but they also introduced many other major social welfare 
schemes such as unemployment insurance and old-age allowances in the 1990s and the 2000s. As much previous scholarship points out, ${ }^{57}$ this rapid expansion of welfare regimes in two countries is mainly attributable to consolidated democratic competitions.

I contend, however, that the two countries have also developed increasingly different structures of civic spheres after the transition to democracy and that these differences have driven them to follow increasingly divergent paths of welfare state development, paths not easily detectable on the basis of spending measures. ${ }^{58} \mathrm{I}$ again focus on the different configurations of formal sectors and find that the Taiwanese formal sector comes increasingly closer to the Argentine one, if to a lesser degree, while the structure of the South Korean formal sector may be increasingly comparable to the Brazilian one. Yet, in contrast to Latin American economies plagued with chronic debt and foreign currency crises accompanied by extremely high inflation (see Appendix 1), East Asian developing countries that have achieved high economic growth and sound, balanced budgets had sufficient degrees of freedom for expanding social safety nets even when confronting the economic crises in the late 1990s. When Latin American countries suffered the pressures of the politics of retrenchment across the entire region, East Asian countries relished the politics of expansion for social policies. Under these situations, formal-sector leaders of Taiwan and South Korea made their own ideological or strategic choices regarding social policy expansion. While the South Korean case confirms the validity of the old social democratic power-resource route, the Taiwanese case verifies "the politics of disarticulation," which I proposed earlier in the Argentine case.

The connectivity of Taiwanese civic spheres was initially characterized by the weak cohesiveness and weak embeddedness of the formal sphere in 1995, even if both dimensions of connectivity became somewhat stronger over time. Table 3 shows that the cohesiveness within the formal sector of both unions and parties in Taiwan was the lowest among the four countries in 1995, but Taiwanese parties and unions

\footnotetext{
${ }^{57}$ Wong 2004; Haggard and Kaufman 2008.

${ }^{58}$ It is difficult to find comparable social spending data for the two countries, as each country reported data to different international agencies based on different criteria. In 2009 South Korea spent roughly 7 percent of GDP for social expenditure (OECD SOCX), while Taiwan spent roughly 15 percent (ILO Social Security Inquiry). However, once educational spending is excluded, Taiwan's figure will be adjusted to roughly 10 percent of GDP. In the late 1990s their social security expenditures were almost identical (Ramesh 2004). A dramatic increase in Taiwan's direct cash transfer programs during the last decade largely accounts for the growing gap between two countries. As the South Korean universal pension program has not yet fully developed, its pension spending stays at a fairly low level (1.4 percent of GDP, the lowest among the OECD countries).
} 


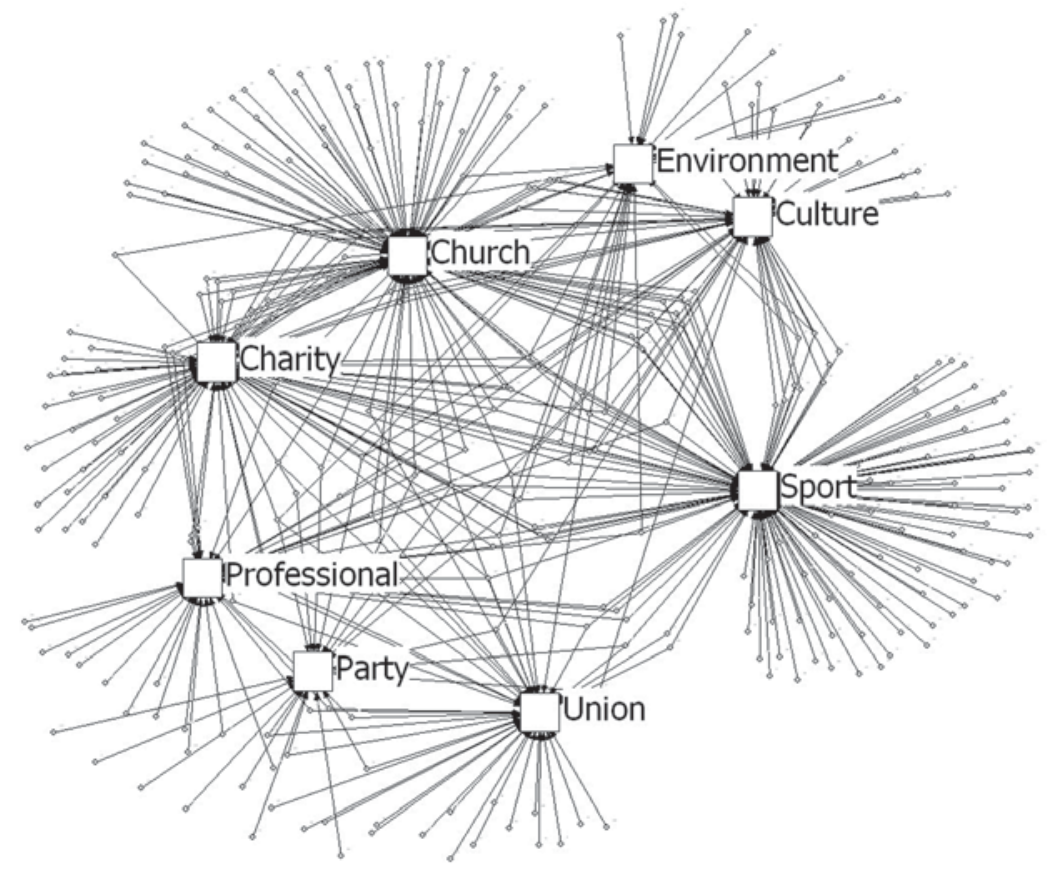

Figure 5

Associational Networks Based on Comembership Data for Taiwan, 2005

rapidly strengthened their interorganizational ties within the formal sector over the course of a decade, while remaining disconnected from the informal civic sphere. Figure 5 shows that parties in Taiwan have some visible connections with unions but are barely connected with other nonformal civic associations. Epitomizing the disarticulated cohesiveness in Taiwanese politics was the conversion in the mid-1990s of the Taiwanese ruling party, the KMT, from an antiwelfare conservative force to a pro-welfare centrist party. ${ }^{59}$ Confronting growing electoral challenges from the opposition party (the DPP), backed up by a coalition of civil society groups ${ }^{60}$ advocating ambitious universal health

\footnotetext{
${ }^{59}$ The KMT, despite its half-century-long rule, did not develop organizational bases in grassroots civil society (see Table 4). This low embeddedness, however, also allowed it to transform itself quickly into a centrist party often supporting social policy provisions against the interests of its traditional supporters, such as employers.
}

${ }^{60}$ Wong 2004. 
care, pension, and guaranteed income policies, the bulk of which rely on direct cash transfers, the KMT eventually pushed for progressive social policy reforms, launching national health insurance in 1995 and unemployment insurance for all workers in 1999, as preemptive policy initiatives just before the legislative elections in 1996 and 2000. As the DPP prioritized old-age pensions as its main platform, ${ }^{61}$ expanding its electoral base to the rural areas that were traditional KMT strongholds, the mainstream faction of the KMT determined to respond to this electoral challenge by advocating correspondingly radical pro-welfare reforms.

In contrast to the Taiwanese social welfare revolution (over health care and employment insurance) led by the conservative government or to the compromise solution (over pensions) between a weak reformist government and a strong conservative legislature, nearly all major universal social policies in South Korea were introduced by incumbent reformist policymakers, in alliance with strong pro-welfare "advocacy coalitions" 62 from civil society groups. ${ }^{63}$ The growth of pro-welfare civil society forces in South Korea coincided exactly with the decline of contentious politics and the growth of the cohesiveness and embeddedness of the formal institutional sphere. After the turbulent eruptions of democratization, labor strikes, and diverse social movements in the 1980s and early 1990s, South Korean associational fields began in the mid-1990s to experience the rapid institutionalization of movement organizations and agendas. Both unions and political parties suffered sharp declines in their memberships, but simultaneously key leaders of such formal organizations started building close ties with other main actors in formal and informal civic spheres. In Table 2, the membership counts for the formal sector decreased significantly, ${ }^{64}$ but

${ }^{61}$ Fell 2005.

${ }^{62}$ Kwon 2003; Sabatier 1988.

${ }^{63}$ For instance, while, in Taiwan, the KMT policymakers initiated and finalized the universal health care reform from the very inception of the policy-crafting process, dominating legislative efforts from other party (the DPP) or civil society groups (Wong 2004), in South Korea, national health care reform in 1999 was an outcome of decade-long conflicts and negotiations between labor, capital, parties, and relevant social forces, since peasant groups protested against unequal benefits and administrative structures in 1988. Both national labor and peasant confederations and civil society groups consisting of seventy-seven organizations (the Solidarity Council for Health Care Reform) set as their primary goal the reform of the segmented corporatist structures of health care administrations into a unitary universal structure; bipartisan efforts (agreements) responding to this pressure passed the bill unanimously in the middle of the financial crisis in 1997.

${ }^{64} \mathrm{~A}$ reviewer wondered about the effect of prior level of (Putnam's) civic associational membership on welfare states. However, both level and change information of associational membership in Table 2 do not significantly contribute to explaining variations in the welfare states of the four countries. They simply capture the rich stock of social capital in Brazil, and indicate little difference among Argentina, South Korea, and Taiwan. South Korea holds a bit higher stock (especially stock II) than the other 
in Table 3, both leaders of parties and unions dramatically increased their ties within the formal sector $(0.25$ to 0.83 for unions and 0.23 to 1 for parties) and with informal civic organizations outside the formal sector (1.13 to 2 for unions and 1 to 2.08 for parties). Parties and unions increased their share of personnel resources through comembership ties and also become more closely connected with communitylevel informal civic organizations, as illustrated in Figure $6 .{ }^{65}$ Within a decade, both the cohesiveness and the embeddedness of the South Korean formal sector surpassed those of Brazil, which was ranked at the top among the four case countries in 1995.

In particular, the introduction of government-guaranteed basic income, which is known as the minimum living standard guarantee (MLSG), is a good example of civil society-driven welfare reforms. It is stipulated as a citizen's basic right rather than as the state's selective assistance to the needy. Among civil society groups, the role of People's Solidarity for Participatory Democracy (PSPD) was decisive in putting national guaranteed income on the table during and after the financial crisis. The PSPD formed a strong "advocacy coalition" composed of twenty-six influential civic associations including the Korean Federations of Trade Unions (KFTU), Citizens' Coalition for Economic Justice (CCEJ), and the Korean Women's Associations United (KWAU), and then kept up pressure upon both the ruling reformist party and the opposition conservative party for the adoption of a "national minimum living standard." ${ }^{66}$ An important distinction between the PSPD-led advocacy coalitions and other pressure groups was that it had allies not only in the ruling party but also in the government bureaucracy and the opposition conservative party. The coalition ignited competition between the two parties by promoting a legislative petition that allied it with a representative of the opposition conservative party, while keeping up the pressure on allies in the ruling party to pass actual legislation. After the law was proposed, while it was passing through the standing committee of the National Assembly, and under intense scrutiny and

two, but there is little change over time in each of the three countries. In contrast to this stability in membership stock, embeddedness captured by intersectoral comemberships varies noticeably over time in all three countries, where there are dramatic changes in their welfare states. The South Korean case, showing different directions of membership stock and comembership linkages during the course of the institutionalization of associational spheres, highlights the importance of the "relational approach" over the conventional "stock-based" approach.

${ }^{65}$ The difference is less pronounced compared with the Argentina-Brazil contrast, but the parties and unions are clearly more densely connected to each other and to other nonformal civic associations in South Korea than in Taiwan.

${ }^{66}$ Kim and Kwon 2008, 232. 


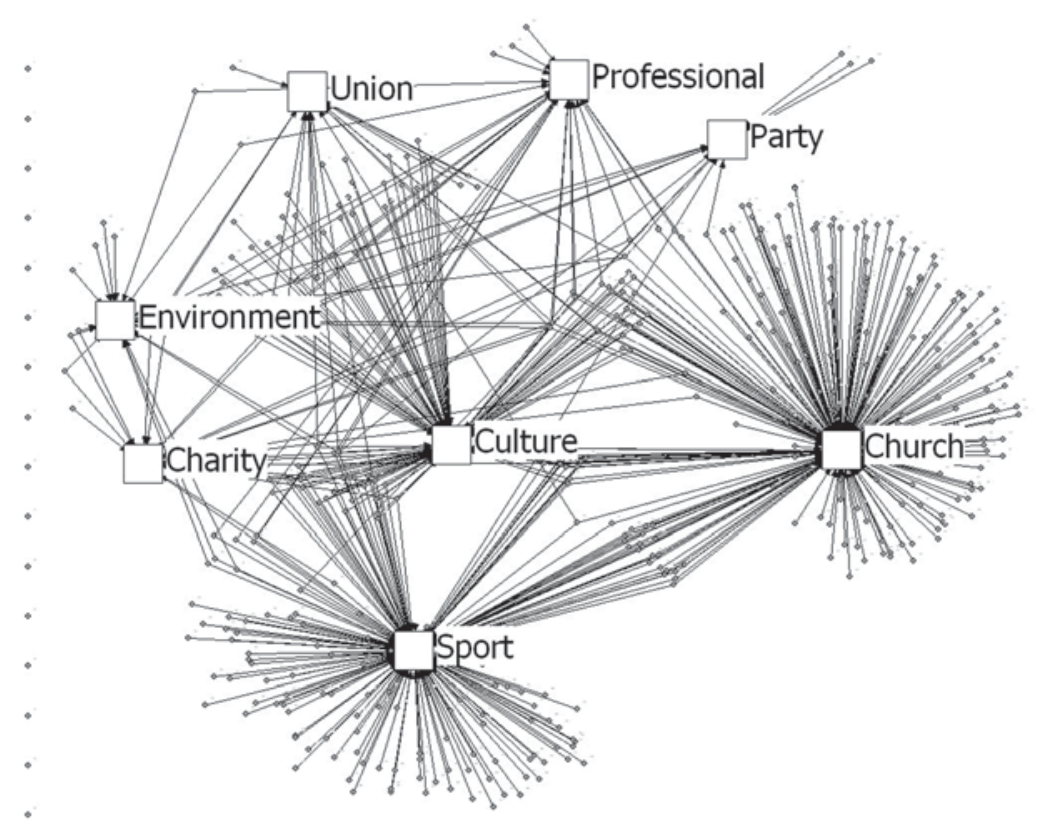

Figure 6

Associational Networks Based on Comembership Data for South KoREA, 2005

debate from different ministries within the government for follow-up enforcement regulations, the coalition continued to play a significant role in maintaining the original spirit and content of the regulations during each step of the legislative and implementation process. ${ }^{67}$

The most illustrative example of the difference in the policy mobilization and crafting processes between the two countries is the politics of old-age pensions. Taiwan's old-age pension basically consists of three different subsystems that can hardly be called a unitary national pension scheme: one for state and public sector employees, another for subscribers of established firms to preexisting labor insurance, and another for formerly uncovered populations, mostly nonemployed, un-

${ }^{67}$ The recent emergence of strong pro-welfare alliances beyond policy-making technocrats and professionals (such as lawyers, doctors, and academics) in South Korea and the active involvement of political parties in the discourse about universal welfare policies reflect this growth in the strength of cohesiveness and embeddedness of formal-sector organizations. 
employed, and self-employed..$^{68}$ Considering the relatively large public sector in Taiwan, this fragmented pension system is less likely to generate effective solidaristic risk pooling and redistribution effects. This fragmented structure results in "uneven levels of benefit to different segments of the population." ${ }^{99}$ The fragmented structure was the product of a political compromise between the DPP (the Democratic Progressive party) government and the KMT-dominated legislature. On the one hand, the KMT wanted neither to endorse the incumbent DPP's long-held platform (old-age pension) nor to be depicted as an antiwelfare force by opposing the quasi-cash transfer program for the formerly uninsured in the informal sector. On the other hand, without strong support from civil society encompassing both the working and the middle class, but with strong opposition from its significant financial supporters (small business), the incumbent DPP government did not have enough capacity to pass the original universal scheme through the hostile legislature. This is how three different pillars of pension schemes eventually came to coexist in a fragmented form under the name of "national pension." The KMT's two completely different platforms on social welfare depending upon their incumbency suggest that its policy orientation is based completely on electoral needs and tactics.

However, in South Korea, an old-age pension program was introduced as a single-pillar scheme with strong redistributive income transfer components from corporate employees in the formal sectors to nonemployed or self-employed citizens in the rural and urban informal sectors. Even some segments of labor unions and middle-class NGOs were initially strongly opposed to this single-pillar redistributive system, but the newly elected reformist government succeeded in implementing the progressive single-pillar scheme with strong support from the more progressive elements within unions and civil society groups.

In Taiwan, both main parties, the KMT and the DPP, have shown strong interest in expanding the social policy regime. Their mutual competition was initially driven by the DPP's ambitious cash transfer programs designed to compete with the KMT's vote buying, ${ }^{70}$ which was later matched by the KMT's preemptive reform initiatives. However, being disarticulated from the wider civil society, neither party had sufficient capacity to persuade and coordinate its own party members

\footnotetext{
${ }^{68}$ The newly added one for the former noninsured does not require any contributions from employers; the insured person's flat rate contribution (60 percent) is combined with the government's flat rate funding (40 percent).

${ }^{69}$ Ramesh 2004, 14.

${ }^{70}$ Fell 2005.
} 
as well as different interest groups and social forces to mobilize around a single-pillar system. As a result, a large part of the Taiwanese social welfare schemes consists of direct cash transfers targeted toward specific groups, rather than universal programs that embrace different segments of populations under a unitary redistributive scheme. Therefore, overall social expenditures increased rapidly, but key insurance systems remained fragmented.

\section{Embedded Cohesiveness vs. Disarticulated Cohesiveness}

In this section, I move beyond comparison within regions. I define the Argentine and Taiwanese cases as examples of disarticulated cohesiveness, while classifying the Brazilian and South Korean cases as embedded cohesiveness. In this classification across regions, I initially formulate a causal path tree that accounts for divergent outcomes of welfare politics, contingent upon the level of cohesiveness and embeddedness, and the partisanship of incumbent governments (Figure 7). I then focus on the structural positions of labor unions in associational communities and their consequences for welfare politics in terms of changes over time for both independent and dependent variables (see Figure 8 and Table 5).

Figure 7 proposes causal pathways using two main explanatory factors and an additional variable (partisan incumbency), as well as expansion or retrenchment outcomes for welfare states in four developing countries. All four countries are exposed to initial pressures originating from globalization and democratization. Severe financial crisis and fierce political competition (after transition to democracy) put similar pressures on elites and leaders of formal politics in these countries; nonetheless, these countries have followed different trajectories, depending upon their organizational capacity as determined by their various modes of linkages.

In theory, with low cohesiveness, I would assume that there would be little interorganizational capacity to push forward radical reform projects regardless of embeddedness and incumbent partisanship. Therefore, no action will be taken for the rest of the trees. ${ }^{71}$ Depending upon the level of embeddedness, however, strong cohesiveness would be expected to diverge toward different outcomes. With both high embeddedness and high cohesiveness, reformist governments inheriting

\footnotetext{
${ }^{71}$ Under limited democracy, in which formal and informal organizations are not fully developed yet, a (former authoritarian) incumbent right-wing party may have the autonomy to initiate policy reforms even without allies in the formal sector, as the KMT's 1995 health care reform illustrates.
} 


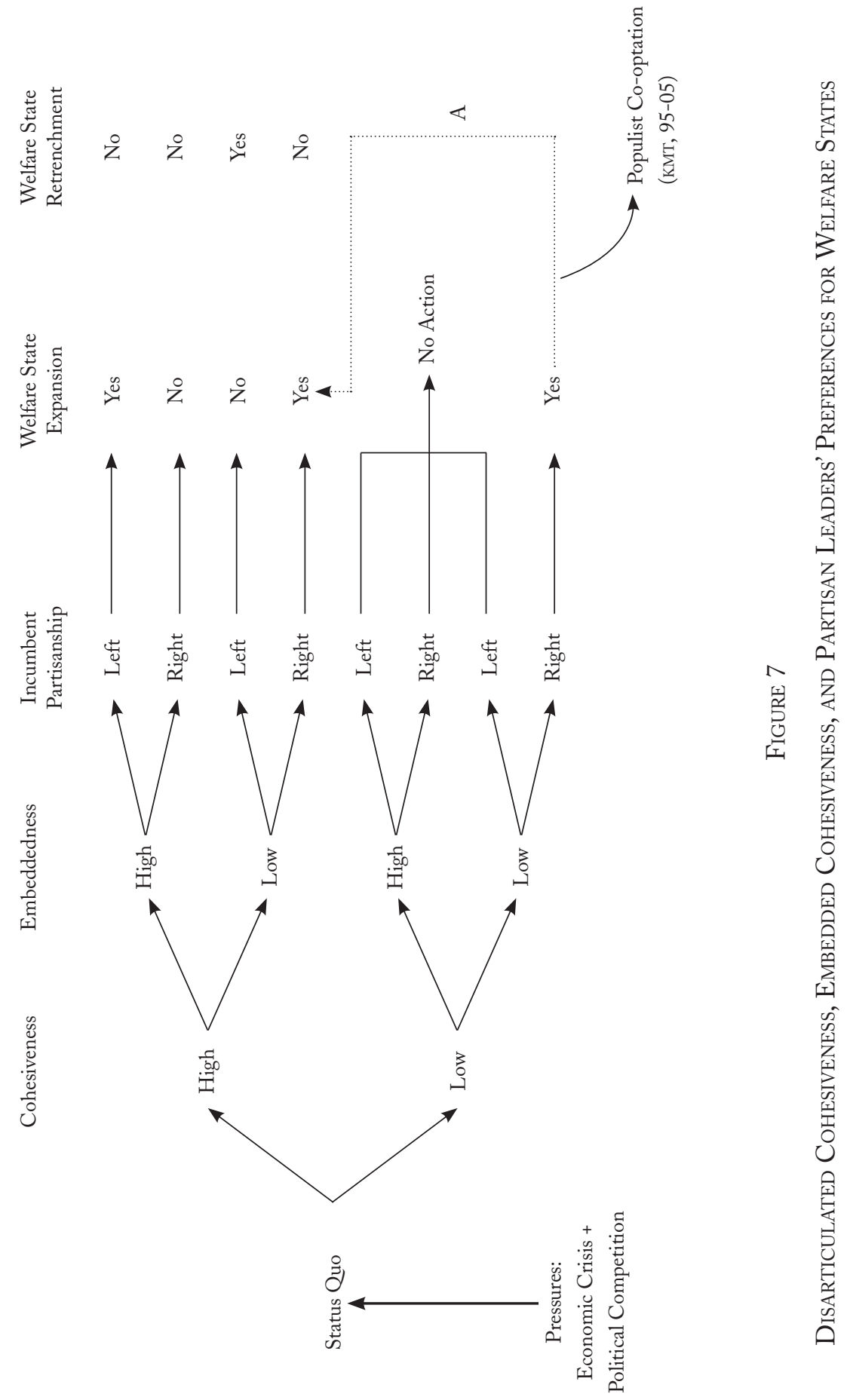




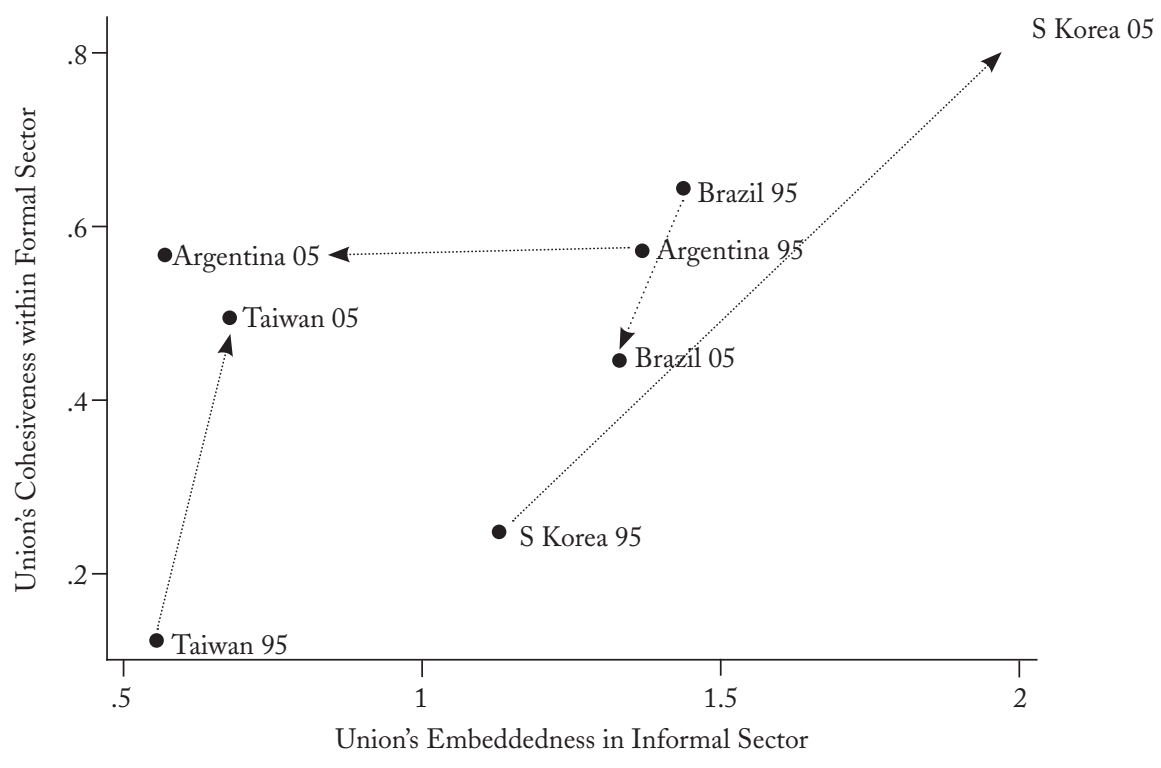

FiguRE 8

Union's Cohesiveness within Formal Sector and EmbedDEDNEsS in Informal Civic Sphere in Four Countries, 1995-2005

good growth records and a sound budget situation will launch expansionary programs toward universal welfare states (South Korea). Even in the event that they inherit an economic crisis (over budget, currency, or debt) from a previous regime, they would not retrench the existing welfare state, as happened in Brazil. Being surrounded by the cohesive formal-sector organizations embedded in supporting civic associations, even a right-wing or center-right government-such as the Lee regime in recent South Korea (2008-) or the Cardoso regime in Brazil (19952002) - would not be able to push radical neoliberal reform programs, although neither would launch any new generous welfare programs.

Over-time changes of cohesiveness and embeddedness in Figure 8 and Table 5 lend credence to this scenario. Figure 8 shows that, with Brazil maintaining its strong case as an example of embedded cohesiveness without noticeable changes over time in both cohesiveness and embeddedness, South Korean labor unions' upward move in both dimensions toward another instance of embedded cohesiveness is impressive. Consequently, while little (or weak negative) changes lead to virtually no change in major social policy are as (or moderate adjustment) 


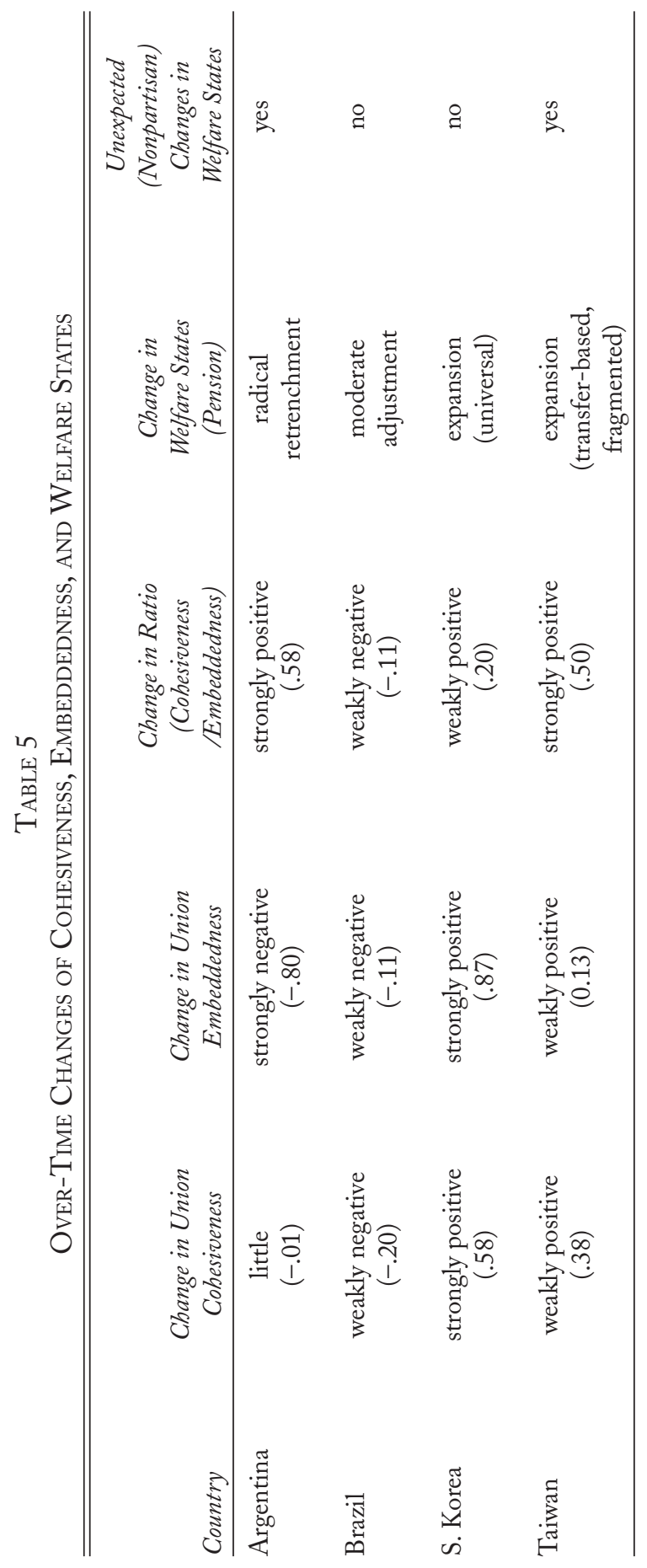


in Brazil, a very strong positive change brings in universal expansion of major social policy schemes in South Korea (see Table 5). ${ }^{72}$ I conceptualize these over-time tendencies not only as a greater incorporation of unions into social democratic politics but also as a greater engagement of unions in community-based informal solidarity. Strong political trust built upon strong linkages of unions with other formal-sector associations is deeply embedded in community-based informal civic lives in these two countries.

To sum up, the politics of embedded cohesiveness is associated with protecting the welfare sector even under severe economic crisis or ambitiously expanding universal social policies under reformist governments. In both Brazil and South Korea, the clear commitments of reformist parties or progressive civic associations to guarantee citizens' general welfare and living conditions against destructive market competitions were stable (Brazil) or strengthened over time (South Korea), and they were underpinned by the organizational linkages within the formal sector and between the formal and informal civic spheres in both countries. The leaders of cohesively linked (labor-based) formal organizations, being deeply embedded in the informal civic sphere, have been aggressively channeling the demands for more universal and generous social protections from the wider class and community bases, including the middle and working classes.

With the high cohesiveness and low embeddedness path shown in Figure 7, which I have labeled as "disarticulated cohesiveness," partisan governments become nonpartisan in the traditional sense, as they have room to maneuver strategically depending upon their judgments of the potential gains to come from transformative politics. The disarticulated cohesiveness, however, may become unstable over time. The PJ's betrayal of its own traditional party base had driven unions to float without apparent political allies (until Kirchner attempted to restore the relationship in the mid-2000s). In Argentina, labor's linkages with informal civic associations sharply decreased (see Figure 8), as they were alienated from the PJ and therefore lost their mediating positions between the PJ and informal civic community. In Taiwan, the realignments of labor unions with nontraditional allies were accompanied by underdevelopment of ties with informal sectors (Taiwan) relative to

${ }^{72}$ In Table 5, the summary columns of over-time changes in cohesiveness and embeddedness suggest that unions' embeddedness provides a stronger explanatory power than cohesiveness. Unions' cohesiveness explains variations between two East Asian countries and two Latin American countries. However, it does not explain variations within a region: little change is associated with differential outcomes, retrenchment in Argentina, and persistence of welfare states in Brazil. By contrast, changes in embeddedness effectively account for subtle qualitative differences in the changes of welfare states. 
consolidated union's linkages within the formal sector (with the KMT). As a result, labor unions' ratio of linkages with formal associations to linkages with informal associations (column $\mathrm{C}$ divided by column $\mathrm{D}$ in Table 3) have dramatically increased in these two countries $(0.58 / 1.37$ $=\mathbf{0 . 4 2}$ in 1995 to $0.57 / 0.57=\mathbf{1 . 0 0}$ in 2005 in Argentina, and 0.12/0.55 $=\mathbf{0 . 2 2}$ in 1995 to $0.50 / 0.68=\mathbf{0 . 7 4}$ in 2005 in Taiwan). The relative overgrowth of cohesiveness in Taiwan or the dwindling embeddedness in Argentina are not comparable to small changes in Brazil (0.65/1.44 $=0.45$ to $0.45 / 1.33=0.34)$ and South Korea $(0.25 / 1.13=0.22$ to $0.83 / 2.00=0.42$ ). I define these tendencies of disarticulated cohesiveness not only as a greater incorporation (co-optation) of unions into formal-sector machine politics (especially in Taiwan) but also as a greater disarticulation of unions from community-based informal solidarity (especially in Argentina). The third and last columns of Table 5 illustrate that the disarticulated cohesiveness may lead to the cross-partisan moves-neoliberal retrenchment reform by formerly labor-based parties and preemptive reform for generous social policies by formerly authoritarian right-wing parties.

Despite the electoral successes of the PJ's transformative reform politics in Argentina, ${ }^{73}$ with the low cohesiveness and low embeddedness of partisan politics, it is very uncertain whether any further transformative politics in Argentina would be able to bring in effective reform agendas without relying on either populism or clientelism (or both). Also, given that the preferences of both politicians and electorates for cash-transfer programs without more tax revenue have increasingly exacerbated government budget deficits ${ }^{74}$ one is led to wonder whether the Taiwanese welfare state will be able to withstand increasing pressures to retrench in the near future.

\section{Conclusion: The Embedded Cohesiveness and the Politics of Social Protection in the Global Market}

This study brought the configuration of associational networks into the discussion of welfare politics in developing countries and formulated a concept of "embedded cohesiveness," aiming to account for the politics of both retrenchment and expansion in welfare state development in four developing economies under consolidated democracy. It suggests that developing an explanatory model of the politics of welfare states in developing countries should go beyond traditional theories of welfare

${ }^{73}$ Levitsky 2003; Burgess and Levitsky 2003.

${ }^{74}$ Chen 2005. 
states developed mainly on the examples of advanced industrial countries. It contends that the origins and sources of politics of social protection need to be extended to informal civic space and configurations within and outside formal-sector politics beyond narrow phenomena of electoral competitions and alliances. Especially, the strength of political linkage and trust between leaders of formal organizations and citizens of informal civic associations, or simply the embeddedness of the formal sector, along with cohesiveness, emerge as the significant explanatory factors for variations in the politics of social policies in (democratized) developing countries.

When an analytical framework is able to focus on this larger, deeper process of political trust building based on interorganizational ties other than mere political competitions, it can effectively account for the politics of both expansion and retrenchment in social policies. When leaders of the formal sector build entrenched solidarity across different classes and sectors, a reformist government facing economic crisis may be able to conduct essential structural reforms based on supportive and trusting constituents who may be more tolerant of indispensable reforms necessary for the country's survival in the global market. Or, based on such support, a reformist government with a good track record of growth may be able to launch a more ambitious universal social policy that extends its coverage to nontraditional supporters. In such a civic community, leaders of the formal sector will not be disloyal to their old constituents even in a time of crisis. Even were there an opportunity to create new constituents by implementing new policies not included in their traditional platforms, they would not necessarily rush to move in such a new direction. They might do so, however, only under the condition that their old constituents agreed to change their existing platforms to respond to the new risks and challenges arising from rapidly changing economic and political situations.

However, when leaders of the formal sector are not committed to their constituents through grassroots-level connections, they may opt to discard their traditional positions and ideological commitments and switch to opposite platforms that might enhance their chances for electoral survival. This opportunistic gamble is likely feasible when severe economic crisis and electoral competition put the leaders in jeopardy of losing ground in the near future. I argued that the politics of retrenchment of welfare states by a labor-based party or the politics of expansion of welfare states by a conservative party share this common logic of political transformation. 
The central argument of this study is consonant with "the configuration of civil society" argument promoted by Ruschemeyer, Stephens, and Stephens ${ }^{75}$ and Collier and Collier, ${ }^{76}$ and it further refines their central tenets. They commonly argued that a well-developed civil society is conducive to democracy because it provides the working classes with better opportunities to increase their organizational power. Recently, and in line with these previous studies, Sandbrook and colleagues took into account this role of growing civil society as one of the key factors promoting social democracy in the global periphery. They make an important point that dense civil society not only offers a favorable condition for self-organization on the part of the subordinate class but also "reduces the transaction costs of coordinating interests" and "increases the chances that the better argument will prevail." 77 The analysis and evidence of this study improve on these arguments in several respects. I have not only presented the divergent configurations of civil society across different societies, but I have also provided additional causal processes using the notion of "embeddedness" and "trust" 78 represented by organizational ties between the formal and the informal civic associations. While Sandbrook and colleagues (rightly) emphasized the emergence of communicative reason (in Habermas's sense) in densely linked civil society, I have focused on the structure of civic associational networks, highlighting the strategic choices of formal-sector elites regarding the expansion or retrenchment of the public sector, contingent upon their having socially embedded relationships of trust with informal civic spheres. I believe that in future studies, it would be valuable to incorporate the communicative, cognitive aspects of civil society and public spheres and the organizational, structural aspects of civil society in a single explanatory framework that could account for democracy and welfare-state development in developing societies.

Many students of welfare state development in developing countries point out that social welfare programs in those states are often devised for the privileged working class in the formal sector, to the exclusion of a large segment of the populations in the urban and rural informal sectors. ${ }^{79}$ Trade unions' alliances with populist regimes in Latin America made them skeptical about the role of labor unions in promoting universal social policies in developing societies. I have showed that, in

\footnotetext{
${ }^{75}$ Rueschemeyer, Stephens, and Stephens 1992.

${ }^{76}$ Collier and Collier 1991.

${ }^{77}$ Sandbrook et al. 2007, 184

${ }^{78}$ Coleman 1990; Granovetter 1985; Tilly 2005.

${ }^{79}$ Haggard and Kaufman 2009; Lee 2005; Rudra 2008; Sandbrook et al. 2007.
} 
societies in which unions are deeply embedded in informal civic associations, labor unions, as a traditional power-resource approach predicts, still play a meaningful role in resisting retrenchment or in sponsoring more generous and comprehensive social policies. I conclude that union embeddedness is essential for preventing the working class from being seduced by the selective co-optation strategy of a populist regime.

I also contend that reformist political projects based on embedded cohesiveness are relatively immune to the pressures of globalization, a point that directly refutes the argument that globalization foils traditional social democratic projects to build more generous and comprehensive welfare states by weakening essential state-centered activities such as the imposition of higher taxes and the protection of labor rights. The comparative case studies and evidence presented in this study show that globalization does not explain variations in the outcome - that is, the (universal) expansion and retrenchment of existing welfare states. Argentina and Brazil, sharing similar debt crises and long histories of exposure to foreign capital, showed significantly different reactions to common structural reform pressures from neoliberal market forces. In Brazil, both the Cardoso regime and the Lula regime were initially constrained by economic crisis, but through their second terms, market-oriented reform pressure did not lead to the radical transformation of Brazilian social policy institutions. Taiwan and South Korea-both sharing export-led industrial structures, similar positions in the world economy, and high levels of capital opennessshowed somewhat different trajectories of welfare state development. Importantly, globalization itself did not frustrate or constrain any efforts of national governments to expand or protect existing welfare states with the exception of Argentina. Rather, as the South Korean and Brazilian cases illustrate, cohesively embedded reformist leaders utilize the pressures of international market forces as an opportunity to expand existing social welfare schemes to formerly uncovered, vulnerable populations.

Also, globalization may increase the demands of the middle classes for more comprehensive social insurance systems, as they come to feel increasingly threatened by and vulnerable to the growing volatility of financial situations. The middle classes in Taiwan and South Korea, which increasingly became pro-welfare forces regardless of political partisanship, also support this scenario. In a sense, the impact of globalization on the politics of social protection may also be contingent upon the degree and mode of the social embeddedness of formal politics. 
With stronger embeddedness, the pressures of globalization may urge leaders of the formal sector to protect or expand welfare states to defend their traditional constituents. However, with weak embeddedness, globalization may provide disarticulated formal-sector leaders not only with incentives but also with justifications for departing from their existing constituents. In short, globalization may strengthen partisan loyalty, but it may also facilitate complete realignments or prolonged chaotic transformative coalitions among politicians or within machine politics regardless of voters' desires, as can be observed in post-Menem Argentina.

Recently, there have been many scholarly efforts to explore the conditions and prospects of social democracy in the global periphery, as left-wing or center-left governments take power after decades of dominance by neoliberalism in political and economic arenas. For this study, however, I intentionally chose country cases that are not yet deemed social democracies. All of the cases have recently emerged from intense authoritarian regimes and have had only about two decades for peaceful democratic electoral cycles; indeed, they are still in the process of consolidating democratic institutions to enhance transparency and accountability. All four cases still have powerful coalitions of conservative blocs left over from their respective authoritarian anciens régimes. The influence of big businesses (South Korea), agrarian landlord classes and foreign capital (Argentina and Brazil), and corrupt machine politics (Taiwan and Argentina) still looms over the prospects of democracy. A key ingredient of social democracy-long-term incumbency of leftwing governments ${ }^{80}$ - is not yet in sight in these countries, as even center-left incumbency is often halted or limited by strong right-wing alliances (South Korea and Taiwan) or its own transformation (Argentina). Nevertheless, I find that exploring these countries under conditions of democratic consolidation is as fruitful as exploring any other exemplary cases of welfare states, because these cases offer living examples of struggles for equality through democratic competition. There are valuable lessons to be learned from their stories of frustrations from betrayal, lack of capacity, strategic mistakes, and ongoing hope for new politics and reforms. I believe that the notion of "embedded cohesiveness" contributes to the understanding of these divergent stories of the politics of social protection and that it has the potential to account for more stories from other places and other times.

${ }^{80}$ Huber and Stephens 2001. 


\section{ApPENDIX 1}

Basic Economic and Demographic Data for Four Countries in the 1990s AND 2000s.

\begin{tabular}{|c|c|c|c|c|c|c|c|c|}
\hline & \multicolumn{2}{|c|}{ Argentina } & \multicolumn{2}{|c|}{ Brazil } & \multicolumn{2}{|c|}{ South Korea } & \multicolumn{2}{|c|}{ Taiwan $^{\mathrm{a}}$} \\
\hline & 1995 & 2005 & 1995 & 2005 & 1995 & 2005 & 1995 & 2005 \\
\hline $\begin{array}{l}\text { GDP per capita, } \\
\operatorname{PPP}(\$)\end{array}$ & 9616 & 10819 & 7724 & 8505 & 15761 & 22783 & 15067 & 26657 \\
\hline $\begin{array}{l}\text { Age structure } \\
\text { (65 years } \\
\text { and over) }\end{array}$ & & 10.6 & & 6 & & 8.6 & & 9.6 \\
\hline $\begin{array}{l}\text { Total Debt } \\
\text { (Domestic + } \\
\text { Foreign) } \\
\text { (\% of GDP) }\end{array}$ & 33.8 & 70.3 & 39.6 & 60.3 & 10.2 & 30 & 12 & 38.5 \\
\hline $\begin{array}{l}\text { Inflation } \\
\quad \text { (annual \%) }\end{array}$ & $\begin{array}{c}3 \\
(1994)\end{array}$ & 9 & $\begin{array}{l}2252 \\
(1994)\end{array}$ & 7 & 7 & 1 & & 2 \\
\hline GINI & 49 & 50 & 59 & 56 & $\begin{array}{c}32 \\
(1998)\end{array}$ & & $\begin{array}{c}32 \\
(1998)\end{array}$ & \\
\hline $\begin{array}{l}\text { Social } \\
\quad \text { Expenditure I } \\
\text { (\% of GDP) }\end{array}$ & $\begin{array}{c}13.9 \\
(2000)\end{array}$ & 12.8 & $\begin{array}{c}12.0 \\
(2000)\end{array}$ & 12.7 & $\begin{array}{c}5.0 \\
(2000)\end{array}$ & 6.9 & $\begin{array}{l}10.36^{\mathrm{a}} \\
(2000)\end{array}$ & $14.86^{\mathrm{a}}$ \\
\hline $\begin{array}{l}\text { Social } \\
\text { Expenditure II } \\
\text { (\% of GDP) } \\
\text { (Excluding Edu } \\
\text { but including pr } \\
\text { sector welfare sp }\end{array}$ & & & & & $\begin{array}{c}9.4 \\
(1998)\end{array}$ & & $\begin{array}{c}9.2 \\
(1999)\end{array}$ & \\
\hline
\end{tabular}

SouRCES: World Bank 2011. Total debt data are drawn from UNCTAD 2008. Social Expenditure I is from ILO 2010-11; Social Expenditure II is from Ramesh 2004.

${ }^{\mathrm{a}}$ Taiwanese Social Expenditure I includes public spending on education.

\section{APPENDIX 2 \\ Measurement of Cohesiveness And Embeddedness in Associational Networks}

In order to measure the structure of associational communities in four developing countries, I utilize data on memberships with voluntary associations in two waves of World Values Surveys, 1995 and 2005. Membership questionnaires contained in these two waves provide important information by asking whether respondents are active or 
nonactive members for a specific association. ${ }^{81}$ The individual-level survey data on memberships with voluntary associations allow me to build an analytical map of each national associational community to explore "how individuals in a society are affiliated with different types of voluntary organizations," "how these individuals and organizations are connected to each other through comemberships," and "how these affiliation networks are aggregated into a distinctive pattern of organizational power structure and configuration"(Lee 2007, 594).

Then, based on the two-mode information ( $\mathrm{m}$ individuals ${ }^{*} \mathrm{n}$ associational types), I built an $n^{*} n$ coaffiliation matrix (Breiger 1974; Borgatti et al. 2002) using UCINET 6. The matrix is composed of diagonal elements representing the number of memberships for each association and nondiagonal elements featuring the number of comemberships between two associational types. With this comembership matrix, I calculated the measures of cohesiveness and embeddedness as follows.

$$
\begin{aligned}
& \text { Cohesiveness of Formal Organizational Sphere }=\sum\left(C M_{\mathrm{i}, \mathrm{j}}\right) / \\
& \begin{aligned}
M(\text { min })_{\mathrm{u}, \mathrm{pa}, \mathrm{pr}} \\
=\left(C M_{\mathrm{u}, \mathrm{pa}}+C M_{\mathrm{u}, \mathrm{pr}}+C M_{\mathrm{pa}, \mathrm{pr}}\right) / M(\text { min })_{\mathrm{u}, \mathrm{pa}, \mathrm{pr},}
\end{aligned}
\end{aligned}
$$

where $C M_{\text {u,pa }}, C M_{\text {u,pr }}$, and $C M_{\text {pa,pr }}$ denote comembership between unions and parties, comembership between union and professional associations, and comembership between parties and professional associations, respectively. $M(\min )_{\text {upa, pr }}$ denotes membership count of three key formal organizations, excluding any redundant memberships (for example, even though a respondent is coaffiliated with all three associations, only one membership will be recorded for the respondent).

$$
\begin{aligned}
& \begin{array}{r}
\text { Embeddedness of Formal Organizational Sphere }=\sum\left(C M_{\mathrm{i}, \mathrm{k}}\right) / \\
M\left(\text { min }_{\mathrm{u}, \mathrm{pa}, \mathrm{pr}} \quad(\mathrm{i} \neq \mathrm{k}, \mathrm{i}=\text { any of formal civic associations, }\right.
\end{array} \\
& =\sum\left(C M_{\mathrm{u}, \mathrm{k}}\right)+\sum\left(C M_{\mathrm{pa}, \mathrm{k}}\right)+\sum\left(C M_{\mathrm{pr}, \mathrm{k}}\right) / M\left(\text { min }_{\mathrm{u}, \mathrm{pa}, \mathrm{pr},}\right.
\end{aligned}
$$

where the numerator denotes the sum of all comembership counts between formal civic associations and informal civic associations. More specifically, the numerator includes the sum of comemberships between unions and all informal civic associations $\left(\sum\left(C M_{\mathrm{u}, \mathrm{k}}\right)\right)$, the sum

\footnotetext{
${ }^{81}$ I utilize only "active members" to construct a comembership matrix among eight associational types (church, cultural clubs, labor unions, political parties, professional associations, environmental associations, sport clubs, and charity groups) for each country module. I believe that when I use active members, excluding nonactive members, I can capture the structure of "leadership networks" of civic associational community more correctly.
} 
of comemberships between parties and all informal civic associations $\left(\Sigma\left(C M_{\mathrm{pa}, \mathrm{k}}\right)\right)$, and the sum of comemberships between professional associations and all informal civic associations $\left(\sum\left(C M_{\mathrm{pr}, \mathrm{k}}\right)\right)$.

\section{REFERENCES}

Aldrich, Howard E., and Martin Ruef. 2006. Organizations Evolving, 2nd ed. Thousand Oaks, Calif.: Sage.

Ames, Barry. 2001. The Deadlock of Democracy in Brazil: Interests, Identities and Institutions. Ann Arbor, Mich.: University of Michigan Press.

Avritzer, Leonardo. 2009. Participatory Institutions in Democratic Brazil. Baltimore, Md.: Johns Hopkins University Press.

Auyero, Javier. 1999. “'From the Client's Point(s) of View': How Poor People Perceive and Evaluate Political Clientelism." Theory and Society 28, no. 2 (April): 297-334.

-2000. Poor People's Politics: Peronist Survival Networks and the Legacy of Evita. Durham, N.C.: Duke University Press.

Baiocchi, Gianpaolo, Patrick Heller, and Marcelo Silva. 2011. Bootstrapping Democracy: Transforming Local Governance and Civil Society in Brazil. Stanford, Calif.: Stanford University Press.

Baldwin, Peter. 1990. The Politics of Social Solidarity: Class Bases of the European Welfare State 1875-1975. Cambridge, UK: Cambridge University Press.

Borgatti, Stephen, Martin G. Everett, and Linton C. Freeman. 2002. UCinET 6 for Windows: Software for Social Network Analysis. Harvard, Mass.: Analytic Technologies.

Branford, Sue, and Bernardo Kucinski. 2003. Politics Transformed: Lula and the Workers Party in Brazil. New York, N.Y.: New Press.

Brooks, Sarah M. Social Protection and the Market in Latin America: The Transformation of Social Security Institutions. New York, N.Y.: Cambridge University Press.

Burgess, Katrina, and Steven Levitsky. 2003. "Explaining Populist Party Adaptation in Latin America: Environmental and Organizational Determinants of Party Change in Argentina, Mexico, Peru, and Venezuela." Comparative Political Studies 36, no. 8 (October): 881-911.

Calvo, Ernesto, and M. Victoria Murillo. 2008. "When Parties Meet Voters: Partisan Networks and Distributive Expectations in Argentina and Chile." Paper presented at the annual meeting of American Political Science Association, Boston, August 28-31.

Cameron, David R. 1978. "The Expansion of the Public Economy: A Comparative Analysis." American Political Science Review 72, no. 4 (December): 124361.

Carey, John M., and Matthew Soberg Shugart. 1994. "Incentives to Cultivate a Personal Vote: A Rank Ordering of Electoral Formulas." Electoral Studies 14, no. 4: 417-39.

Chen, Chien-Hsun. 2005. "Taiwan's Burgeoning Budget Deficit: A Crisis in the Making?" Asian Survey 45, no. 3 (May-June): 383-96. 
Chalmers, Douglas A., Scott B. Martin, and Kerianne Piester. 1998. "Associative Networks: New Structures of Representation for the Popular Sectors?" In Douglas A. Chalmers, Carlos M. Vilas, Katherine Hite, Scott B. Martin, Kerianne Piester, and Monique Segarra, eds., The Nerw Politics of Inequality in Latin America: Rethinking Participation and Representation. New York, N.Y.: Oxford University Press.

Coleman, James S. 1990. Foundations of Social Theory. Cambridge, Mass.: Belknap Press of Harvard University Press.

Collier, Ruth B., and David Collier. 1991. Shaping the Political Arena: Critical Junctures, the Labor Movement, and Regime Dynamics in Latin America. Princeton, N.J.: Princeton University Press.

Collier, Ruth Berins, and Samuel Handlin. 2009. "General Patterns and Emerging Differences." In Ruth B. Collier and Samuel Handlin, eds., Reorganizing Popular Politics: Participation and the New Interest Regime in Latin America. University Park, Pa.: Pennsylvania State University Press.

De La O, Ana. 2011. The Politics of Conditional Cash Transfers. New Haven, Conn.: Yale University Press.

Economist. 2010. "Brazil's Bolsa Familia: How to Get Children out of Jobs and into School.” July 29. At http://www.economist.com/node/16690887.

Esping-Andersen, Gøsta. 1985. Politics against Markets. Princeton, N.J.: Princeton University Press.

— 1990. The Three Worlds of Welfare Capitalism. Princeton, N.J.: Princeton University Press.

Etchemendy, Sebastián, and Ruth Berins Collier. 2007. "Down but Not Out: Union Resurgence and Segmented Neocorporatism in Argentina (20032007)." Politics and Society 35, no. 3 (September): 363-401.

Evans, Peter B. 1995. Embedded Autonomy: States and Industrial Transformation. Princeton, N.J.: Princeton University Press.

Fell, Dafydd. 2005. Party Politics in Taiwan: Party Change and the Democratic Evolution of Taiwan, 1991-2004. New York, N.Y.: Routledge.

Gould, Roger V. 1989. "Power and Structure in Community Elites." Social Forces 68, no. 2 (December): 531-52.

-1995. Insurgent Identities: Class, Community, and Protest in Paris from 1848 to the Commune. Chicago, Ill.: University of Chicago Press.

Gould, Roger V., and Roberto M. Fernandez. 1989. "Structures of Mediation: A Formal Approach to Brokerage in Transaction Networks.” Sociological Methodology 19: 89-126.

Granovetter, Mark. 1985. "Economic Action and Social Structure: The Problem of Embeddedness." American Journal of Sociology 91, no. 3 (November): 481-510.

- 2002. "A Theoretical Agenda for Economic Sociology." In Mauro F. Guillén, Randall Collins, Paula England, and Marshall Meyer, eds., The New Economic Sociology: Developments in an Emerging Field. New York, N.Y.: Russell Sage Foundation.

Habermas, Jürgen. 1984. The Theory of Communicative Action I: Reason and the Rationalization of Society. Boston, Mass.: Beacon Press.

- 1987. The Theory of Communicative Action II: Lifeworld and System: A Critique of Functionalist Reason. Boston, Mass.: Beacon Press. 
Haggard, Stephan, and Robert R. Kaufman. Development, Democracy, and Welfare States: Latin America, East Asia, and Eastern Europe. Princeton, N.J.: Princeton University Press.

Hall, Anthony. 2008. "Brazil's Bolsa Familia: A Double-Edged Sword?” Development and Change 39, no. 5 (September): 799-822.

Heclo, Hugh. 1974. Modern Social Politics in Britain and Sweden. New Haven, Conn.: Yale University Press.

Huber, Evelyne, and John D. Stephens. 2001. Development and Crisis of the Welfare State: Parties and Policies in Global Markets. Chicago, Ill.: University of Chicago Press.

Huber, Evelyne, François Nielsen, Jenny Pribble, and John D. Stephens. 2006. "Politics and Inequality in Latin America and the Caribbean." American Sociological Review 71, no. 6 (December): 943-63.

Hunter, Wendy. 2010. The Transformation of the Workers' Party in Brazil, 19892009. New York, N.Y.: Cambridge University Press.

International Labour Office. 2010-11. World Social Security Report: Providing Coverage in Times of Crisis and Beyond. Geneva, Switzerland: at http://www .ilo.org.

International Social Security Association. 2008-9. Social Security Programs throughout the World: Asia and the Pacific. At http://www.ssa.gov/policy/docs/ progdesc/ssptw/.

Katzenstein, Peter J. 1985. Small States in World Markets: Industrial Policy in Europe. Ithaca, N.Y.: Cornell University Press.

Kay, Stephen J. 2000. "The Politics of Postponement: Political Incentives and the Sequencing of Social Security Reforms in Argentina and Uruguay." Paper presented at the Year 2000 International Research Conference on Social Security, Helsinki, September 25-27. At http://www.issa.int/pdf/helsinki2000/ topic1/2kay.pdf.

Keck, Margaret. 1992. The Workers' Party and Democratization in Brazil. New Haven, Conn.: Yale University Press.

Kitschelt, Herbert, and Steven I. Wilkinson. 2007. "Citizen-Politician Linkages: an Introduction," In Herbert Kitschelt and Steven I. Wilkinson, eds., Patrons, Clients, and Policies: Patterns of Democratic Accountability and Political Competition. New York, N.Y.: Cambridge University Press.

Kollock, Peter. 1994. "The Emergence of Exchange Structures: An Experimental Study of Uncertainty, Commitment, and Trust." American Journal of Sociology 100, no. 2 (September): 313-45.

Korpi, Walter. 1983. The Democratic Class Struggle. London, UK: Routledge and Kegan Paul.

Kwon, Huck-Ju. 2003. "Advocacy Coalitions and the Politics of Welfare in Korea after the Economic Crisis." Policy and Politics 31, no. 1 (January): 69-83.

Kwon, Huck-Ju, and Fen-ling Chen. 2007. "Governing Universal Health Insurance in Korea and Taiwan." International Journal of Social Welfare 17, no. 4 (September): 355-64.

Lee, Cheol-Sung. 2005. “Income Inequality, Democracy, and Public Sector Size.” American Sociological Review 70, no. 1 (February): 158-81.

- 2007. "Labor Unions and Good Governance: A Cross-National, Comparative Study." American Sociological Review 72, no. 4 (August): 585-609. 
Levitsky, Steven. 2003. Transforming Labor-Based Parties in Latin America: Argentine Peronism in Comparative Perspective. New York, N.Y.: Cambridge University Press.

Lipton, Michael. 1977. Why Poor People Stay Poor: Urban Bias in World Development. Cambridge, Mass.: Harvard University Press.

Lomeli, Enrique Valencia. 2008. "Conditional Cash Transfers as Social Policy in Latin America: An Assessment of Their Contributions and Limitations." Annual Review of Sociology 34: 475-99.

Luebbert, Gregory M. 1991. Liberalism, Fascism, or Social Democracy: Social Classes and the Political Origins of Regimes in Interwar Europe. New York, N.Y.: Oxford University Press.

Madrid, Raúl L. 2003. Retiring the State: The Politics of Pension Privatization in Latin America and Beyond. Stanford, Calif.: Stanford University Press.

Mainwaring, Scott P. 1999. Rethinking Party Systems in the Third Wave of Democratization: The Case of Brazil. Palo Alto, Calif.: Stanford University Press.

Malloy, James M. 1979. Politics of Social Security in Brazil. Pittsburgh, Pa.: University of Pittsburgh Press.

Mische, Ann. 2008. Partisan Publics: Communication and Contention across Brazilian Youth Activist Networks. Princeton, N.J.: Princeton University Press.

Murillo, Maria Victoria. 2001. Labor Unions, Partisan Coalitions, and Market Reforms in Latin America. New York, N.Y.: Cambridge University Press.

Pampel, Fred, and John Williamson. 1989. Age, Class, Politics and the Welfare State. New York, N.Y.: Cambridge University Press.

Portes, Alejandro, and Julia Sensenbrenner. 1993. "Embeddedness and Immigration: Notes on the Social Determinants of Economic Action." American Journal of Sociology 98, no. 6 (May): 1320-50.

Putnam, Robert. 1993. Making Democracy Work: Civic Traditions in Modern Italy. Princeton, N.J.: Princeton University Press.

- 2000. Bowling Alone: The Collapse and Revival of American Community. New York, N.Y.: Simon and Schuster.

Ramesh, M. 2004. Social Policy in East and Southeast Asia: Education, Health, Housing, and Income Maintenance. New York, N.Y.: RoutledgeCurzon.

Rawlings, Laura B. 2005. "A New Approach to Social Assistance: Latin America's Experience with Conditional Cash Transfer Programmes.” International Social Security Review 58, no. 2-3 (July): 133-61.

Roberts, Kenneth M. 2006. "Populism, Political Conflict, and Grass-Roots Organization in Latin America." Comparative Politics 38, no. 2 (January): 127-48.

Rudra, Nita. 2008. Globalization and the Race to the Bottom in Developing Countries: Who Really Gets Hurt? New York, N.Y.: Cambridge University Press.

Rueschemeyer, Dietrich, Evelyne Huber Stephens, and John D. Stephens. 1992. Capitalist Development and Democracy. Chicago, Ill.: University of Chicago Press. Sabatier, Paul A. 1986. "Top-down and Bottom-up Approach to Implementation Research: A Critical Analysis and Suggested Synthesis." Journal of Public Policy 6, no. 1 (November): 21-48.

Sandbrook, Richard, Marc Edelman, Patrick Heller, and Judith Teichman. 2007. Social Democracy in Global Periphery: Origins, Challenges, Prospects. New York, N.Y.: Cambridge University Press. 
Scott, W. Richard. 2008. Institutions and Organizations: Ideas and Interests, 3rd ed. Thousand Oaks, Calif.: Sage.

Shugart, Matthew Soberg, and John M. Carey. 1992. Presidents and Assemblies: Constitutional Design and Electoral Dynamics. New York, N.Y.: Cambridge University Press.

Skocpol, Theda. 1992. Protecting Mothers and Soldiers. Cambridge, Mass.: Harvard University Press.

Stephens, John D. 1979. The Transition from Capitalism to Socialism. London, UK: Macmillan.

Stokes, Susan C. 2007. "Political Clientelism," In Carles Boix and Susan C. Stokes, eds., The Oxford Handbook of Comparative Politics. New York, N.Y.: Oxford University Press.

Tilly, Charles. 2005. Trust and Rule. New York, N.Y.: Cambridge University Press.

United Nations Conference on Trade and Development (UNCTAD). 2008. "Domestic and External Debt in Developing Countries." Discussion Paper no.188, March. Data available at http://ideas.repec.org/p/unc/dispap/188.html, accessed September 2011.

Weir, Margaret, Ann Shola Orloff, and Theda Skocpol. 1988. "Introduction: Understanding American Social Politics.” In Margaret Weir, Ann Shola Orloff, and Theda Skocpol, eds., The Politics of Social Policy in the United States. Princeton, N.J.: Princeton University Press.

Weyland, Kurt. 1996. Democracy without Equity: The Failure of Reform in Brazil. Pittsburgh, Pa: University of Pittsburgh Press.

Wilensky, Harold. 1975. The Welfare State and Equality. Berkeley, Calif.: University of California Press.

Wong, Joseph. 2004. Healthy Democracies: Welfare Politics in Taiwan and South Korea. Ithaca, N.Y.: Cornell University Press.

World Bank. 2011. World Development Indicators. Washington, D.C. At http:// data.worldbank.org, accessed September, 2011. 